\title{
Contributions of individual reactive biogenic volatile organic compounds to organic nitrates above a mixed forest
}

\author{
K. A. Pratt ${ }^{1}$, L. H. Mielke ${ }^{1, *}$, P. B. Shepson ${ }^{1,2,3}$, A. M. Bryan ${ }^{4}$, A. L. Steiner ${ }^{4}$, J. Ortega ${ }^{5, * *}$, R. Daly ${ }^{5, * * *}$, D. Helmig ${ }^{5}$,

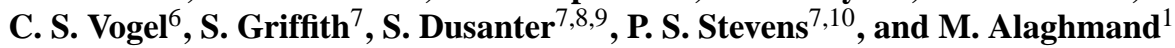 \\ ${ }^{1}$ Department of Chemistry, Purdue University, West Lafayette, IN, USA \\ ${ }^{2}$ Department of Earth, Atmospheric, and Planetary Sciences, Purdue University, West Lafayette, IN, USA \\ ${ }^{3}$ Purdue Climate Change Research Center, Purdue University, West Lafayette, IN, USA \\ ${ }^{4}$ Department of Atmospheric, Oceanic and Space Sciences, University of Michigan, Ann Arbor, MI, USA \\ ${ }^{5}$ Institute of Arctic and Alpine Research, University of Colorado, Boulder, CO, USA \\ ${ }^{6}$ University of Michigan Biological Station, Pellston, MI, USA \\ ${ }^{7}$ School of Public and Environmental Affairs, Indiana University, Bloomington, IN, USA \\ ${ }^{8}$ Université Lille Nord de France, Lille, France \\ ${ }^{9}$ École des Mines de Douai, Douai, France \\ ${ }^{10}$ Department of Chemistry, Indiana University, Bloomington, IN, USA \\ * now at: School of Public and Environmental Affairs, Indiana University, Bloomington, IN, USA \\ ** now at: Atmospheric Chemistry Division, Earth System Laboratory, National Center for Atmospheric Research, \\ Boulder, CO, USA \\ *** now at: Air Pollution Prevention and Control Division, National Risk Management Research Laboratory, \\ US Environmental Protection Agency, Research Triangle Park, NC, USA
}

Correspondence to: K. A. Pratt (kapratt@purdue.edu)

Received: 20 May 2012 - Published in Atmos. Chem. Phys. Discuss.: 11 July 2012

Revised: 27 September 2012 - Accepted: 16 October 2012 - Published: 5 November 2012

\begin{abstract}
Biogenic volatile organic compounds (BVOCs) can react in the atmosphere to form organic nitrates, which serve as $\mathrm{NO}_{\mathrm{x}}\left(\mathrm{NO}+\mathrm{NO}_{2}\right)$ reservoirs, impacting ozone and secondary organic aerosol production, the oxidative capacity of the atmosphere, and nitrogen availability to ecosystems. To examine the contributions of biogenic emissions and the formation and fate of organic nitrates in a forest environment, we simulated the oxidation of 57 individual BVOCs emitted from a rural mixed forest in northern Michigan. Key BVOCoxidant reactions were identified for future laboratory and field investigations into reaction rate constants, yields, and speciation of oxidation products. Of the total simulated organic nitrates, monoterpenes contributed $\sim 70 \%$ in the early morning at $\sim 12 \mathrm{~m}$ above the forest canopy when isoprene emissions were low. In the afternoon, when vertical mixing and isoprene nitrate production were highest, the simulated contribution of isoprene-derived organic nitrates was greater than $90 \%$ at all altitudes, with the concentration of secondary
\end{abstract}

isoprene nitrates increasing with altitude. Notably, reaction of isoprene with $\mathrm{NO}_{3}$ leading to isoprene nitrate formation was found to be significant ( $\sim 8 \%$ of primary organic nitrate production) during the daytime, and monoterpene reactions with $\mathrm{NO}_{3}$ were simulated to comprise up to $\sim 83 \%$ of primary organic nitrate production at night. Lastly, forest succession, wherein aspen trees are being replaced by pine and maple trees, was predicted to lead to increased afternoon concentrations of monoterpene-derived organic nitrates. This further underscores the need to understand the formation and fate of these species, which have different chemical pathways and oxidation products compared to isoprene-derived organic nitrates and can lead to secondary organic aerosol formation. 


\section{Introduction}

Globally, biogenic volatile organic compound (BVOC) emissions $\left(\sim 1150 \mathrm{Tg} \mathrm{Cyr}^{-1}\right)$ comprise $\sim 90 \%$ of total nonmethane VOC emissions, and isoprene and monoterpenes alone are estimated to account for $\sim 55 \%$ of total nonmethane VOC emissions (Guenther et al., 1995; Goldstein and Galbally, 2007). These BVOCs typically have atmospheric lifetimes of minutes to hours for reactions with the hydroxyl $(\mathrm{OH})$ radical, ozone $\left(\mathrm{O}_{3}\right)$, and the nitrate $\left(\mathrm{NO}_{3}\right)$ radical (Atkinson and Arey, 2003a). In the atmosphere, BVOCs exist as complex mixtures with individual BVOC mole fractions ranging from a few ppb to subppt (Bouvier-Brown et al., 2009). The chemistry and fate of atmospheric BVOCs have important implications for ozone and secondary organic aerosol production, yet many questions remain regarding these processes (Goldstein and Galbally, 2007).

Tropospheric ozone is produced via oxidation of NO to $\mathrm{NO}_{2}$ by organic peroxy radicals and $\mathrm{HO}_{2}$ (e.g., Hauglustaine et al., 1996). Organic nitrates serve as $\mathrm{NO}_{\mathrm{x}}\left(\mathrm{NO}+\mathrm{NO}_{2}\right)$ reservoirs. Therefore, they impact nitrogen availability to ecosystems (Lockwood et al., 2008), ozone production (both locally and downwind) (e.g., Fiore et al., 2005; Wu et al., 2007; Farmer et al., 2011; Paulot et al., 2012), and the oxidative capacity of the atmosphere, impacting trace gas removal and secondary organic aerosol formation and processing (e.g., Rollins et al., 2010). Organic nitrates $\left(\mathrm{RONO}_{2}\right)$ are formed via reactions of VOCs with $\mathrm{OH}$ in the presence of NO, as shown in Reactions (1)-(3), which show H-atom abstraction from a $\mathrm{C}-\mathrm{H}$ bond, followed by $\mathrm{O}_{2}$ addition yielding a peroxy radical that can react with $\mathrm{NO}$ to produce $\mathrm{RONO}_{2}$ (Orlando et al., 2003).

$$
\begin{aligned}
& \mathrm{RH}+\mathrm{OH} \rightarrow \mathrm{R}^{\cdot}+\mathrm{H}_{2} \mathrm{O} \\
& \mathrm{R}^{\cdot}+\mathrm{O}_{2} \rightarrow \mathrm{RO}_{2} \\
& \mathrm{RO}_{2}+\mathrm{NO}^{\cdot} \rightarrow \mathrm{RONO}_{2}
\end{aligned}
$$

Alternatively, organic nitrates can also be formed from VOCs through addition of $\mathrm{NO}_{3}$ or $\mathrm{OH}$, followed by peroxy radical formation and reaction with NO. Olefins constitute the largest VOC emission flux globally, and $\mathrm{OH}$ reactions with olefins are primarily via addition. Therefore, most organic nitrates are "multifunctional" (O'Brien et al., 1995) and not simple "alkyl nitrates", produced via $\mathrm{H}$-atom abstraction. Organic nitrates have been shown to be a major component (12$20 \%$ ) of $\mathrm{NO}_{\mathrm{y}}$ (measured as $\mathrm{NO}+\mathrm{NO}_{2}+\mathrm{HNO}_{3}+$ peroxy acetyl nitrates $+\mathrm{RONO}_{2}$ ) over the eastern United States during summer (Perring et al., 2009a). During the aircraft-based study by Perring et al. (2009a), $75 \%$ of the organic nitrates below $0.5 \mathrm{~km}$ were estimated to be derived from isoprene. At night, isoprene nitrates formed via reaction of isoprene with $\mathrm{NO}_{3}$ were estimated to comprise $2-9 \%$ of $\mathrm{NO}_{\mathrm{y}}$ (Brown et al., 2009). Correspondingly, modeled tropospheric ozone production rates and concentrations are sensitive to isoprene emission rates and the yield of isoprene nitrates (Fiore et al., 2005; Wu et al., 2007). Further, the fate of organic nitrates and associated recycling of $\mathrm{NO}_{\mathrm{x}}$ is highly uncertain, even for isoprene, the most abundant BVOC (Horowitz et al., 2007).

While the measurement of a large contribution of organic nitrates to $\mathrm{NO}_{\mathrm{y}}$ raises important questions about their nature and sources, measurement of the contributions of specific $\mathrm{RONO}_{2}$ compounds in the atmosphere remains an analytical challenge, due to low ambient concentrations and the adsorptive nature of multifunctional nitrates (e.g., Muthuramu et al., 1993). Thus, few atmospheric measurements of speciated organic nitrates from BVOC precursors exist; in fact, only select nitrates resulting from isoprene oxidation have been measured (Werner et al., 1999; Grossenbacher et al., 2001, 2004; Giacopelli et al., 2005; Beaver et al., 2012). Isolation of specific $\mathrm{RONO}_{2}$ isomers is further complicated by secondary chemistry and loss processes (Giacopelli et al., 2005), the contributions of which change spatially and temporally (Day et al., 2003).

The rural mixed forest environment at the University of Michigan Biological Station (UMBS) in northern Michigan is an excellent location for studying the atmospheric chemistry of a wide variety of individual BVOCs. At this site, the forest composition and succession are well characterized (Bergen and Dronova, 2007), and the tree species-specific fluxes of BVOCs have been measured (Ortega et al., 2007, 2008). Together, this unique information and the well-studied atmospheric environment at UMBS represent a unique opportunity to study the specifics of BVOC-derived organic nitrate production. This study utilized a simple atmospheric chemistry one-dimensional model to simulate the formation and fate of organic nitrates produced from the oxidation of 57 individual BVOCs locally emitted at UMBS. Several previous studies of BVOCs have utilized more complex onedimensional modeling to gain insight into local-scale chemistry (Trainer et al., 1991; Gao et al., 1993; Makar et al., 1999; Spanke et al., 2001; Stroud et al., 2005; Forkel et al., 2006; Boy et al., 2011; Mogensen et al., 2011; Wolfe and Thornton, 2011; Wolfe et al., 2011a, b; Rinne et al., 2012). These recent BVOC-focused modeling studies combine detailed micrometeorology with atmospheric chemistry to simulate chemistry in and above the forest canopy. The goal of this study was to investigate the full suite of the 57 BVOCs observed to be emitted in the UMBS forest; however, existing chemical mechanisms cannot capture this large number of BVOC species. For example, one of the most complex mechanisms at this time is the Master Chemical Mechanism (MCM, http://mcm.leeds.ac.uk/MCM); yet of the BVOCs emitted at UMBS, this mechanism only includes isoprene, $\alpha$-pinene, $\beta$-pinene, limonene, and $\beta$-caryophyllene. Further, most chemical mechanisms require lumped species, not allowing the examination of individual BVOCs. These various BVOCs are characterized by different and complex chemical structures, resulting in variations in reactivity, as well 
as different oxidation products with subsequently different lifetimes, which are often not represented by lumped categories. Therefore, the model herein includes a simplified atmospheric treatment with more complex chemistry to investigate the contributions of the full suite of observed BVOCs to organic nitrate production and concentrations with respect to time of day and height above the forest canopy. As the aspen forests (Populus grandidentata and Populus tremuloides) in the upper Great Lakes region are maturing and will be replaced by northern hardwoods (Acer rubrum, Acer saccharum, Fagus grandifola) and upland pine (Pinus strobus, Pinus resinosa) (Bergen and Dronova, 2007), the impacts of forest succession on atmospheric composition are also examined. The focus of this study was to highlight the role of individual BVOC contributions to organic nitrate formation and to identify key species that require further examination in future laboratory and field studies.

\section{Experimental}

\subsection{Measurements}

Atmospheric summertime BVOC emissions and oxidation chemistry were evaluated in northern Michigan at the Program for Research on Oxidants: Photochemistry, Emissions and Transport (PROPHET) tower site at the University of Michigan Biological Station (UMBS, $45^{\circ} 30^{\prime} \mathrm{N}, 84^{\circ} 42^{\prime} \mathrm{W}$, elevation $238 \mathrm{~m}$ ) (Carroll et al., 2001). An AmeriFlux site is located $132 \mathrm{~m}$ north-northeast of the PROPHET tower. The nearest town is Pellston, Michigan (population $<800$ ), located $\sim 5.5 \mathrm{~km}$ to the west; Detroit, Michigan is the nearest major metropolitan area, $\sim 350 \mathrm{~km}$ to the southeast. To eliminate the need to account for wet deposition, only sunny and partly sunny days with no precipitation during JulyAugust 2008 were considered for the following analysis. Ambient air measurements of isoprene, total monoterpenes, methacrolein (MACR), and methyl vinyl ketone (MVK) were conducted using the proton-transfer reaction linear ion trap mass spectrometer (PTR-LIT), described previously by Mielke et al. $(2008,2010)$, sampling at $\sim 34 \mathrm{~m}$ above ground ( $\sim 12 \mathrm{~m}$ above canopy) at UMBS in July-August 2008. NO, $\mathrm{NO}_{2}$, and $\mathrm{NO}_{\mathrm{y}}^{*}\left(\sim \mathrm{NO}_{\mathrm{y}}-\mathrm{HNO}_{3}\right)$ were measured using a custom chemiluminescence instrument with thermal decomposition inlets, constructed following the designs of Ridley and Grahek (1990), Bollinger et al. (1983), and Day et al. (2002). All times are given in Eastern Standard Time (EST), one hour behind Eastern Daylight Time.

\subsection{Model description}

A simplified atmospheric chemistry one-dimensional model was constructed to simulate the emissions, transport, and reactions of 57 locally-produced BVOCs at the UMBS PROPHET site. The atmosphere was represented by 25 vertical bins, including 2 bins within the forest canopy, extending from $12 \mathrm{~m}$ above the surface to approximately $4 \mathrm{~km}$; due to the simplicity of the canopy bins, atmospheric chemistry is only discussed for the bins above the forest canopy. BVOC concentrations were calculated according to transport and reaction kinetics following Eq. (1), which describes the change in the concentration $(c)$ of $\mathrm{VOC}_{i}$ at altitude $z$ and with time $t$ :

$\frac{\mathrm{d} c_{i}(z)}{\mathrm{d} t}=E_{i}+P_{i}+F_{\downarrow, i}-L_{i}-F_{\uparrow, i}-D_{i}-H_{i}$

VOC terms, described below, include emission $(E)$ into the first canopy bin, chemical production $(P)$ and loss $(L)$ based on chemical kinetics, upward and downward vertical fluxes ( $F_{\uparrow}$ and $F_{\downarrow}$, respectively), dry deposition $(D)$, and horizontal advection $(H)$. The model time step was $0.2 \mathrm{~s}$, and one day of spin-up was utilized prior to the model day discussed.

\subsubsection{BVOC emissions}

Based on mean green-leaf dry mass, characterized during litter trap studies of 101 plots in 2008 and 2010, the local UMBS forest $\left(1.4 \mathrm{~km}^{2}\right)$ is primarily composed of bigtooth aspen (Populus grandidenta, $\sim 23 \%$ ), red maple (Acer rubrum, $\sim 23 \%$ ), red oak (Quercus rubra, $\sim 22 \%$ ), quaking aspen (Populus tremuloides, $\sim 8 \%$ ), sugar maple (Acer saccharum, $\sim 7 \%$ ), paper birch (Betula papyrifera, $\sim 7 \%$ ), white pine (Pinus strobus, $\sim 7 \%$ ), American beech (Fagus grandifolia, $\sim 3 \%$ ), and red pine (Pinus resinosa, $\sim 1 \%$ ). The average canopy height is $\sim 22 \mathrm{~m}$. Speciated emission rates were measured from these individual tree species by branch-enclosure experiments, including measurements at UMBS during the summers of 2003, 2005 (Ortega et al., 2007, 2008), 2009, and 2010; thus, these emission rate measurements are expected to be characteristic of the modeled summer emissions. A total of 57 BVOCs were identified, including isoprene, 2 aromatics, 3 alkanes, 20 monoterpenes (MTs), 8 oxygenated species, and 23 sesquiterpenes (SQTs), and are shown in Tables 1 and $\mathrm{S} 1$. To estimate emission rates for the whole canopy, the basal emission rates $\left(\mu g \mathrm{~g} \mathrm{~g}^{-1} \mathrm{~h}^{-1}\right)$ for each compound were multiplied by the mean green-leaf dry mass $\left(\mathrm{g} \mathrm{m}^{-2}\right)$ for each tree species, obtained through litter trap studies. To estimate future BVOC emissions due to forest succession predicted by Bergen and Dronova (2007), a simplified replacement of aspen (Populus grandidentata, Populus tremuloides) by northern hardwoods (Acer rubrum, Acer saccharum, Fagus grandifola) or upland pine (Pinus strobus, Pinus resinosa) was carried out and is described in the supporting information.

Since isoprene emission is both temperature- and lightdependent, its diurnal emission rates were calculated according to the algorithm given by Guenther et al. (1993), which includes light and temperature correction factors $\left(C_{\mathrm{PAR}}\right.$ and $C_{T}$, respectively):

$\mathrm{ER}(T, \mathrm{PAR})=\mathrm{ER}\left(T_{\mathrm{S}}\right) \cdot C_{\mathrm{PAR}} \cdot C_{T}$ 
Table 1. BVOCs identified during branch-enclosure emission measurements for UMBS tree species. Corresponding reaction rate constants (units of $\mathrm{cm}^{3} \mathrm{molec}^{-1} \mathrm{~s}^{-1}$ ) for $\mathrm{OH}, \mathrm{O}_{3}$, and $\mathrm{NO}_{3}$ at $298 \mathrm{~K}$ ( $k_{\mathrm{OH}}, k_{\mathrm{O} 3}$, and $k_{\mathrm{NO} 3}$, respectively) and $\mathrm{RONO}_{2}$ yields for reactions with $\mathrm{OH}$ and $\mathrm{NO}_{3}\left(\gamma_{\mathrm{OH}}\right.$ and $\gamma_{\mathrm{NO}}$, respectively) are included for each BVOC identified. Individual BVOCs are displayed in order of simulated $\mathrm{RONO}_{2}$ contribution; BVOCs contributing $<0.5 \mathrm{ppt}$ $\mathrm{RONO}_{2}$ (at $\sim 12 \mathrm{~m}$ above forest canopy) are shown in Table S1.

\begin{tabular}{|c|c|c|c|}
\hline BVOC & Structure & $\begin{array}{l}k_{\mathrm{OH}} k_{\mathrm{O} 3} k_{\mathrm{NO}} \\
\left(\mathrm{cm}^{3} \mathrm{molec}^{-1} \mathrm{~s}^{-1}\right)\end{array}$ & $\begin{array}{l}\mathrm{RONO}_{2}: \\
\gamma_{\mathrm{OH}} \gamma_{\mathrm{NO} 3}\end{array}$ \\
\hline $\begin{array}{l}\text { isoprene } \\
\left(\mathrm{C}_{5} \mathrm{H}_{8}\right)\end{array}$ & & $\begin{array}{l}1.0 \times 10^{-10, \mathrm{a}} \\
1.27 \times 10^{-17, \mathrm{a}} \\
7.0 \times 10^{-13, \mathrm{a}}\end{array}$ & $\begin{array}{l}0.07^{\mathrm{b}} \\
0.68^{\mathrm{c}}\end{array}$ \\
\hline $\begin{array}{l}\text { trans-ocimene } \\
\left(\mathrm{C}_{10} \mathrm{H}_{16}\right)\end{array}$ & & $\begin{array}{l}3.03 \times 10^{-10, \mathrm{~d}} \\
3.85 \times 10^{-16, \mathrm{~d}} \\
2.20 \times 10^{-11, \mathrm{e}}\end{array}$ & $\begin{array}{l}0.18^{\mathrm{f}} \\
0.31^{\mathrm{g}}\end{array}$ \\
\hline $\begin{array}{l}\text { limonene } \\
\left(\mathrm{C}_{10} \mathrm{H}_{16}\right)\end{array}$ & & $\begin{array}{l}1.64 \times 10^{-10, \mathrm{e}} \\
2.1 \times 10^{-16, \mathrm{e}} \\
1.22 \times 10^{-11, \mathrm{e}}\end{array}$ & $\begin{array}{l}0.28^{\mathrm{h}} \\
0.30^{\mathrm{i}}\end{array}$ \\
\hline $\begin{array}{l}\beta \text {-pinene } \\
\left(\mathrm{C}_{10} \mathrm{H}_{16}\right)\end{array}$ & & $\begin{array}{l}7.43 \times 10^{-11, \mathrm{e}} \\
1.5 \times 10^{-17, \mathrm{e}} \\
2.51 \times 10^{-12, \mathrm{e}}\end{array}$ & $\begin{array}{l}0.23^{\mathrm{j}} \\
0.43^{\mathrm{k}}\end{array}$ \\
\hline $\begin{array}{l}\alpha-\text { pinene } \\
\left(\mathrm{C}_{10} \mathrm{H}_{16}\right)\end{array}$ & & $\begin{array}{l}5.3 \times 10^{-11, \mathrm{a}} \\
9.0 \times 10^{-17, \mathrm{a}} \\
6.16 \times 10^{-12, \mathrm{e}}\end{array}$ & $\begin{array}{l}0.18^{1} \\
0.20^{\mathrm{m}}\end{array}$ \\
\hline $\begin{array}{l}\gamma \text {-terpinene } \\
\left(\mathrm{C}_{10} \mathrm{H}_{16}\right)\end{array}$ & & $\begin{array}{l}1.77 \times 10^{-10, \mathrm{e}} \\
1.4 \times 10^{-16, \mathrm{e}} \\
2.9 \times 10^{-11, \mathrm{e}}\end{array}$ & $\begin{array}{l}0.18^{\mathrm{f}} \\
0.31^{\mathrm{g}}\end{array}$ \\
\hline $\begin{array}{l}\text { sabinene } \\
\left(\mathrm{C}_{10} \mathrm{H}_{16}\right)\end{array}$ & & $\begin{array}{l}1.17 \times 10^{-10, \mathrm{e}} \\
8.3 \times 10^{-17, \mathrm{e}} \\
1.0 \times 10^{-11, \mathrm{e}}\end{array}$ & $\begin{array}{l}0.23^{\mathrm{n}} \\
0.31^{\mathrm{g}}\end{array}$ \\
\hline $\begin{array}{l}\beta-\text { myrcene } \\
\left(\mathrm{C}_{10} \mathrm{H}_{16}\right)\end{array}$ & & $\begin{array}{l}3.35 \times 10^{-10, \mathrm{~d}} \\
3.85 \times 10^{-16, \mathrm{~d}} \\
1.1 \times 10^{-11, \mathrm{e}}\end{array}$ & $\begin{array}{l}0.18^{f} \\
0.31^{g}\end{array}$ \\
\hline $\begin{array}{l}\text { cis-ocimene } \\
\left(\mathrm{C}_{10} \mathrm{H}_{16}\right)\end{array}$ & & $\begin{array}{l}3.03 \times 10^{-10, \mathrm{~d}} \\
3.85 \times 10^{-16, \mathrm{~d}} \\
2.20 \times 10^{-11, \mathrm{e}}\end{array}$ & $\begin{array}{l}0.18^{f} \\
0.31^{g}\end{array}$ \\
\hline $\begin{array}{l}\alpha \text {-thujene } \\
\left(\mathrm{C}_{10} \mathrm{H}_{16}\right)\end{array}$ & & $\begin{array}{l}7.10 \times 10^{-11, o} \\
6.2 \times 10^{-17, o} \\
5.5 \times 10^{-12, p}\end{array}$ & $\begin{array}{l}0.18^{f} \\
0.31^{g}\end{array}$ \\
\hline
\end{tabular}

${ }^{\mathrm{a}}$ Atkinson et al. (2006), ${ }^{\mathrm{b}}$ Lockwood et al. (2010), ${ }^{\mathrm{c}}$ Average of Perring et al. (2009b) and Rollins et al. (2009), ${ }^{\mathrm{d}} \mathrm{Kim}$ et al. (2011), ${ }^{\mathrm{e}}$ Atkinson and Arey (2003b), ${ }^{\mathrm{f}}$ Estimated based on Arey et al. (2001) and O'Brien et al. (1998), g Average of $\alpha$-pinene, $\beta$-pinene, and limonene yields, ${ }^{\mathrm{h}}$ Leungsakul et al. (2005), ${ }^{\mathrm{i}}$ Fry et al. (2011), ${ }^{\mathrm{j}}$ Davis et al. (2005), ${ }^{\mathrm{k}}$ Fry et al. (2009), ${ }^{1}$ Nozière et al. (1999), ${ }^{\mathrm{m}}$ Spittler et al. (2006), ${ }^{\mathrm{n}} \beta$-pinene used as a proxy, ${ }^{\circ}$ Pinto et al. (2007), ${ }^{\mathrm{p}}$ Estimated based on Pfrang et al. (2006).

$\operatorname{ER}\left(T_{\mathrm{S}}\right)$ is the normalized basal isoprene emission rate at a standard temperature of $303.15 \mathrm{~K}$ and a standard photosynthetic active radiation (PAR) flux of $1000 \mu \mathrm{mol} \mathrm{m}^{-2} \mathrm{~s}^{-1}$. The light correction factor $C_{\mathrm{PAR}}$ is given by:

$C_{\mathrm{PAR}}=\frac{\alpha c_{L 1} \mathrm{PAR}}{\sqrt{1+\alpha^{2} \mathrm{PAR}^{2}}}$ $\alpha(=0.0021)$ and $c_{L 1}(=1.013)$ are coefficients to account for shading that were calculated according to Guenther et al. (1999) (Eq. 4b and c) using a measured leaf area index of $3.1 \mathrm{~m}^{2} \mathrm{~m}^{-2}$ and assuming equal distribution across the $8.8 \mathrm{~m}$ primary canopy bin; these calculated values are similar to those measured by Guenther et al. (1993). Photosynthetic photon flux density was measured at $46 \mathrm{~m}$ above ground at the AmeriFlux tower using a LI-COR PAR sensor. The temperature correction factor $C_{T}$ is given by:

$C_{T}=\frac{\exp \frac{c_{T 1}\left(T-T_{\mathrm{s}}\right)}{R T_{\mathrm{s}} T}}{1+\exp \frac{c_{T 2}\left(T-T_{M}\right)}{R T_{\mathrm{s}} T}}$

where $T$ is the temperature measured at the PROPHET tower at $32 \mathrm{~m}, R$ is the ideal gas constant $\left(8.314 \mathrm{~J} \mathrm{~K}^{-1} \mathrm{~mol}^{-1}\right)$, $T_{\mathrm{S}}$ is the standard temperature $(303.15 \mathrm{~K})$, and $c_{T 1}$ $\left(95000 \mathrm{~J} \mathrm{~mol}^{-1}\right), c_{T 2}\left(230000 \mathrm{~J} \mathrm{~mol}^{-1}\right)$, and $T_{M}(314 \mathrm{~K})$ are empirical coefficients given by Guenther et al. (1993).

At UMBS, MT and SQT emissions are primarily driven by temperature. This was parameterized by an empirical $\beta$ factor, measured for the different tree species during branchenclosure experiments. Therefore, the diurnal emission rates of the BVOCs were calculated according to Guenther et al. (1993):

$\operatorname{ER}(T)=\operatorname{ER}\left(T_{\mathrm{s}}\right) \cdot \exp \beta\left(T-T_{\mathrm{S}}\right)$

$\operatorname{ER}\left(T_{\mathrm{S}}\right)$ is the BVOC emission rate at a standard temperature of $303.15 \mathrm{~K}$. Previous measurements of MT $\beta$-factors showed an average value of $0.14 \mathrm{~K}^{-1}$ with inner-quartile ranges of $0.11-0.17 \mathrm{~K}^{-1}$; the corresponding average SQT $\beta$ factor was $0.17 \mathrm{~K}^{-1}$ with an inner-quartile range of 0.15 $0.21 \mathrm{~K}^{-1}$ (Ortega et al., 2008). These average, upper, and lower $\beta$-factors were utilized for the base, minimum, and maximum production rate scenarios, described below. Of the monoterpenes considered here, trans-ocimene has been shown to be light- and temperature-dependent (Ortega et al., 2007). Thus, the trans-ocimene emission rates were scaled by the light correction factor $C_{\mathrm{PAR}}$ (Eq. 3) and an exponential temperature dependence (Eq. 5).

BVOC emissions were found to vary considerably between individual trees at UMBS (Ortega et al., 2008), similar to previous observations elsewhere by Guenther et al. (1991). Therefore, to examine the model sensitivity to BVOC emissions, three emissions scenarios were constructed as described in the supporting information. For this study, the base emission scenario values are reported, with minimum and maximum values reported in brackets, to evaluate the impacts of measurement uncertainties and emission variability. BVOC volumetric emission rates (molecules $\mathrm{m}^{-3} \mathrm{~s}^{-1}$ ) were calculated by dividing the BVOC fluxes (molecules $\left.\mathrm{m}^{-2} \mathrm{~s}^{-1}\right)$ by the width of the first canopy bin $(8.8 \mathrm{~m})$, which extends from 12.1-20.9 $\mathrm{m}$ above the ground and covers the majority of the leaf biomass at the site (Schmid et al., 2003); thus, for the model, all leaf biomass was assumed to exist in the lowermost bin. As noted above, for the 
light-dependent BVOCs isoprene and trans-ocimene, shading within the large canopy bin was accounted for using the coefficients $\alpha$ and $c_{L 1}$. Despite the fact that multiple finely-resolved canopy bins were not utilized in this model, there was good agreement between measured and modeled above-canopy VOC concentrations (discussed below). This suggests that our treatment with BVOCs being emitted into one large canopy bin was sufficient for the purposes of understanding the local contributions of individual BVOCs to biogenic organic nitrate formation.

\subsubsection{Vertical transport}

The vertical flux of each chemical species $\left(F_{i}\right)$ was calculated as:

$F_{i}=-K_{H, z} \frac{\Delta\left[\mathrm{VOC}_{i}\right]}{\Delta z}$

where $\Delta\left[\mathrm{VOC}_{i}\right]$ is the concentration difference between adjacent bins, and $\Delta z$ is the vertical distance between the centers of these two bins. The vertical transport of BVOCs following emission was described by thermal eddy diffusivity $\left(K_{H}\right)$ profiles based on modeled mixing by the CACHE model (Forkel et al., 2006; Bryan et al., 2012) for sunny and partly sunny days during the summer 2009 CABINEX campaign at UMBS. Mixing within the canopy and up to 1.5 times the canopy height $(1.5 h)$ was parameterized with a modified K-theory that uses observations of vertical velocity standard deviation at two heights within and above the canopy $(0.92 h$ and $1.5 h)$ to account for "near-field" mixing effects (Raupach, 1989). Modeled $K_{H}$ values were linearly interpolated from the modeled $K_{H}$ at the base of the crown space $(6 \mathrm{~m})$ to the first $(20.6 \mathrm{~m} ; 0.92 h)$ and second $(34 \mathrm{~m} ; 1.5 h)$ measurement heights. In this region, $K_{H}$ was scaled by the $R$ factor (Eq. 10 in Makar et al., 1999) using a $\tau / \mathrm{T}_{\mathrm{L}}$ ratio of 4 (Stroud et al., 2005; Wolfe and Thornton, 2011), where $\tau$ is the transport lifetime and $\mathrm{T}_{\mathrm{L}}$ is the Lagrangian timescale. Above the canopy, modeled values according to Forkel et al. (1990) were used up to approximately $4 \mathrm{~km}$ above ground and adjusted to remove the sharp discontinuity between the measurement height and the adjacent model level. The vertical $K_{H}$ profile peaks at $\sim 300 \mathrm{~m}$ above ground (14:45 EST) with a maximum mixing height of $\sim 1 \mathrm{~km}$ (Fig. S1), following Gao et al. (1993).

\subsubsection{BVOC reactions and oxidant measurements}

Once emitted into the model atmosphere, individual BVOCs reacted with $\mathrm{OH}, \mathrm{O}_{3}$, and $\mathrm{NO}_{3}$. Rather than explicitly calculating oxidant concentrations, 0.5 -h resolution average diurnal cycles of $\mathrm{OH}, \mathrm{O}_{3}$, and $\mathrm{NO}_{3}$ were directly input to minimize uncertainties in $\mathrm{O}_{3}$ production (Wu et al., 2007) and $\mathrm{OH}$ recycling under low $\mathrm{NO}_{\mathrm{x}}$ conditions (e.g., Sillman et al., 2002; Hofzumahaus et al., 2009). Above-canopy (32 m above ground) daytime (08:30-18:30) and nighttime [OH] were measured by laser-induced fluorescence (Dusanter et al., 2009) in July-August 2008 and July-August 2009, respectively; these data were combined to provide a full diurnal $\mathrm{OH}$ cycle. Ozone was measured at $32 \mathrm{~m}$ above ground using a Thermo Environmental Instruments model 49C UV absorption ozone analyzer. The $0.5 \mathrm{~h}$ resolution average diurnal cycle of $\mathrm{NO}_{3}$ radical concentrations was calculated using the model described by Hurst et al. (2001); details and modifications are provided in the supporting information. Average diurnal cycles of the concentrations of $\mathrm{OH}, \mathrm{O}_{3}$, and $\mathrm{NO}_{3}$ are shown in Fig. S2. Oxidant concentrations were assumed to be constant with altitude. However, previous modeling scenarios for other locations suggest that $\left[\mathrm{O}_{3}\right]$ and $\left[\mathrm{NO}_{3}\right]$ may increase slightly with increasing height above the forest canopy, while $[\mathrm{OH}]$ may increase with height above the canopy in the daytime and decrease above the canopy at night (Gao et al., 1993; Geyer and Stutz, 2004a, b). However, as discussed below, much of the BVOC oxidation occurs in the lowest $\sim 100 \mathrm{~m}$ of the boundary layer.

The chemical reaction loss rate of each VOC within each bin was calculated as:

$$
\begin{aligned}
L_{i}= & k_{\mathrm{OH}, i} \cdot[\mathrm{OH}] \cdot\left[\mathrm{VOC}_{i}\right]+k_{\mathrm{O} 3, i} \cdot\left[\mathrm{O}_{3}\right] \cdot\left[\mathrm{VOC}_{i}\right] \\
& +k_{\mathrm{NO} 3, i} \cdot\left[\mathrm{NO}_{3}\right] \cdot\left[\mathrm{VOC}_{i}\right]
\end{aligned}
$$

where $k_{\mathrm{OH}, i}, k_{\mathrm{O} 3, i}$, and $k_{\mathrm{NO} 3, i}$ are the respective $\mathrm{OH}, \mathrm{O}_{3}$, and $\mathrm{NO}_{3}$ rate constants for $\mathrm{VOC}_{i}$, as shown in Tables 1 and $\mathrm{S} 1$. When rate constants were not available, they were calculated using the United States Environmental Protection Agency Estimation Program Interface Suite (USEPA, 2010) and the structure activity relations described by Pfrang et al. (2006) and Kerdouci et al. (2010).

Given the abundance of isoprene at UMBS, concentrations of major first-generation isoprene oxidation products MACR and MVK were calculated based on measured yields (Ruppert and Becker, 2000) (Table S5). The isoprene first-generation $\mathrm{C}_{5}$-unsaturated hydroxyaldehyde isomers, referred to as IP-HMY and IP-MHY, were calculated based on Carter and Atkinson (1996) and Costa (2011) (see Table S5).

\subsubsection{Organic nitrates}

Few laboratory studies have measured organic nitrate $\left(\mathrm{RONO}_{2}\right)$ yields from BVOC oxidation. In fact, of the 57 $\mathrm{BVOCs}$ considered here, $\mathrm{RONO}_{2}$ yields have only been measured for isoprene (Tuazon and Atkinson, 1990; Chen et al., 1998; Chuong and Stevens, 2002; Sprengnether et al., 2002; Patchen et al., 2007; Perring et al., 2009b; Rollins et al., 2009; Lockwood et al., 2010; Costa, 2011), $\alpha$-pinene (Hallquist et al., 1999; Nozière et al., 1999; Spittler et al., 2006), $\beta$-pinene (Hallquist et al., 1999; Davis et al., 2005; Fry et al., 2009), and limonene (Hallquist et al., 1999; Leungsakul et al., 2005; Spittler et al., 2006; Fry et al., 2011). Therefore, for the remaining BVOCs and primary organic nitrate species, organic nitrate yields $(\gamma)$ for reaction of BVOCs with $\mathrm{OH}$, and subsequently $\mathrm{NO}$, were first estimated based 
Table 2. Individual primary isoprene nitrate relative yields and corresponding reaction rate constants (units of $\mathrm{cm}^{3} \mathrm{molec}^{-1} \mathrm{~s}^{-1}$ ) are shown; secondary isoprene nitrate yields for reaction with $\mathrm{OH}$ are shown with the specific species showed in Table 3 and with the abbreviation here listed in parentheses. All primary isoprene nitrates are assumed to have secondary $\mathrm{RONO}_{2}$ yields of 0.5 for reaction with $\mathrm{O}_{3}$. For reaction of all primary isoprene nitrates with $\mathrm{NO}_{3}$, yields are assumed to be 0.6 (containing one nitrate group) and 0.4 (dinitrate yield) based on Rollins et al. (2009).

\begin{tabular}{|c|c|c|c|c|}
\hline $\begin{array}{l}\text { Isoprene } \\
\text { Nitrate }\end{array}$ & Structure & $\begin{array}{l}\text { Relative } \\
\mathrm{RONO}_{2} \\
\gamma_{\mathrm{OH}} \\
\gamma_{\mathrm{NO} 3}\end{array}$ & $\begin{array}{l}k_{\mathrm{OH}} k_{\mathrm{O} 3} k_{\mathrm{NO}} 3 \\
\left(\mathrm{~cm}^{3} \mathrm{molec}^{-1} \mathrm{~s}^{-1}\right)\end{array}$ & $\begin{array}{l}\text { Secondary } \\
\mathrm{RONO}_{2} \gamma_{\mathrm{OH}}\end{array}$ \\
\hline $\mathrm{RONO}_{2}-4,3$ & & $\begin{array}{l}0.63^{\mathrm{a}} \\
0^{\mathrm{b}}\end{array}$ & $\begin{array}{l}5.3 \times 10^{-11, c} \\
3.7 \times 10^{-17, d} \\
3.0 \times 10^{-13, d}\end{array}$ & $0.40(\mathrm{MVKN})^{\mathrm{e}}$ \\
\hline $\mathrm{RONO}_{2}-3,4$ & & $\begin{array}{l}0.013^{\mathrm{a}} \\
0^{\mathrm{b}}\end{array}$ & $\begin{array}{l}5.3 \times 10^{-11, \mathrm{c}} \\
3.7 \times 10^{-17, d} \\
3.0 \times 10^{-13, d}\end{array}$ & $\begin{array}{l}0.15(\mathrm{MVKN})^{\mathrm{e}} \\
0.30(\mathrm{ETHLN})^{\mathrm{e}}\end{array}$ \\
\hline $\mathrm{RONO}_{2}-1,2$ & & $\begin{array}{l}0.183^{\mathrm{a}} \\
0^{\mathrm{b}}\end{array}$ & $\begin{array}{l}1.4 \times 10^{-11, c} \\
1.4 \times 10^{-17, d} \\
4.6 \times 10^{-14, d}\end{array}$ & $0.40(\mathrm{MACRN})^{\mathrm{e}}$ \\
\hline $\mathrm{RONO}_{2}-2,1$ & & $\begin{array}{l}0.0747^{\mathrm{a}} \\
0^{\mathrm{b}}\end{array}$ & $\begin{array}{l}2.8 \times 10^{-11, \mathrm{c}} \\
1.4 \times 10^{-17, d} \\
4.6 \times 10^{-14, d}\end{array}$ & $1.0(\mathrm{PROPNN})^{\mathrm{e}}$ \\
\hline $\mathrm{RONO}_{2}-4,1$ & & $\begin{array}{l}0.0795^{\mathrm{a}} \\
0.2^{\mathrm{b}}\end{array}$ & $\begin{array}{l}4.5 \times 10^{-11, \mathrm{c}} \\
1.6 \times 10^{-16, d} \\
4.8 \times 10^{-12, d}\end{array}$ & $0.30(\mathrm{PROPNN})^{\mathrm{e}}$ \\
\hline $\mathrm{RONO}_{2-1,4}$ & & $\begin{array}{l}0.0195^{\mathrm{a}} \\
0^{\mathrm{b}}\end{array}$ & $\begin{array}{l}4.5 \times 10^{-11, c} \\
1.6 \times 10^{-16, d} \\
4.8 \times 10^{-12, d}\end{array}$ & $\begin{array}{l}0.15(\mathrm{MVKN})^{\mathrm{e}} \\
0.30(\mathrm{ETHLN})^{\mathrm{e}}\end{array}$ \\
\hline $\begin{array}{l}\mathrm{NO}_{3-}^{-} \\
\text {NITROX }\end{array}$ & & $\begin{array}{l}0^{\mathrm{a}} \\
0.8^{\mathrm{b}}\end{array}$ & $\begin{array}{l}3.1 \times 10^{-11, c} \\
3 \times 10^{-18, b} \\
5.5 \times 10^{-12, d}\end{array}$ & $0.30(\mathrm{PROPNN})^{\mathrm{b}}$ \\
\hline
\end{tabular}

on the number of carbon atoms $(n)$ within each BVOC (Arey et al., 2001):

$\gamma=(0.0381 \pm 0.0031) n-(0.073 \pm 0.0178)$

To apply this parameterization to alkenes, the calculated yield was multiplied by 0.58 , according to O'Brien et al. (1998). For compounds with oxygen-containing functional groups present in positions $\beta$ or further from the peroxy radical, the calculated yield was multiplied by 1.7 (Espada and Shepson, 2005). The production rate of organic nitrate $i$ was calculated as:

$$
\begin{aligned}
P_{\mathrm{ON}_{i}} & =k_{\mathrm{OH}, i} \cdot[\mathrm{OH}] \cdot\left[\mathrm{VOC}_{i}\right] \cdot \gamma_{\mathrm{OH}, i} \cdot \delta \\
& +k_{\mathrm{NO} 3, i} \cdot\left[\mathrm{NO}_{3}\right] \cdot\left[\mathrm{VOC}_{i}\right] \cdot \gamma_{\mathrm{NO}, i}
\end{aligned}
$$

where $\gamma$ is the $\mathrm{RONO}_{2}$ yield from the reaction of $\mathrm{VOC}_{i}$ with either $\mathrm{OH}$ or $\mathrm{NO}_{3}$. Since $\mathrm{NO}$ was not explicitly calculated within the model, $\mathrm{NO}_{\mathrm{x}}$ conditions were accounted for by the term $\delta$, which describes the fraction of time $\mathrm{RO}_{2}$ reacts with $\mathrm{NO}$ versus $\mathrm{HO}_{2}$ and $\mathrm{RO}_{2}$, as previously described by Barket et al. (2004):

$$
\delta=\frac{k_{\mathrm{RO} 2, \mathrm{NO}}\left[\mathrm{RO}_{2}\right][\mathrm{NO}]}{k_{\mathrm{RO} 2, \mathrm{NO}}\left[\mathrm{RO}_{2}\right][\mathrm{NO}]+k_{\mathrm{RO} 2, \mathrm{HO} 2}\left[\mathrm{RO}_{2}\right]\left[\mathrm{HO}_{2}\right]}
$$

where NO was measured using a customized chemiluminescence instrument, described above, $\mathrm{HO}_{2}$ was measured using laser-induced fluorescence (Dusanter et al., 2009), and $\left[\mathrm{RO}_{2}\right]$ was assumed to equal $\left[\mathrm{HO}_{2}\right]$ (Tan et al., 2001; Mihele and Hastie, 2003). The associated rate constants, based on isoprene reactions, are $9.0 \times 10^{-12}, 3.9 \times 10^{-12}$, and $1.3 \times 10^{-11} \mathrm{~cm}^{3}$ molec $^{-1} \mathrm{~s}^{-1}$ for $k_{\mathrm{RO} 2, \mathrm{NO}}, k_{\mathrm{RO} 2, \mathrm{HO} 2}$, and $k_{\mathrm{RO} 2, \mathrm{RO} 2}$, respectively (Barket et al., 2004). For the average diurnal cycle, measured [NO] reached a minimum of $0.3 \mathrm{ppt}$ 
at 01:30 (EST) and a morning maximum of $326 \mathrm{ppt}$ at 07:30 (EST). Correspondingly, the diurnal cycle of $\delta$, shown in Fig. S3, was calculated to range from 0.03 at $01: 30$ to 0.92 at 07:30, further showing the significant impact of the morning $\mathrm{NO}_{\mathrm{x}}$ maximum (Alaghmand et al., 2011). It should be noted that recent studies have found that instruments that detect $\mathrm{HO}_{2}$ radicals using chemical conversion to $\mathrm{OH}$ by reaction with added NO may be sensitive to the detection of hydroxyalkyl peroxy radicals produced from the OH-initiated oxidation of alkenes (Fuchs et al., 2011). As a result, the $\mathrm{HO}_{2}$ measurements in this study likely represent an upper limit to the actual concentration of $\mathrm{HO}_{2}$ radicals; thus, the calculated $\delta$ and corresponding nitrate production represent lower limits (Fig. S3).

Speciated primary and secondary isoprene nitrates were estimated based on the laboratory studies of Lockwood et al. (2010); Rollins et al. (2009); Paulot et al. (2009); and Costa (2011) (Tables 2 and 3). Structures of all other primary and secondary BVOC nitrates produced by reactions with each oxidant $\left(\mathrm{OH}, \mathrm{O}_{3}\right.$, and $\left.\mathrm{NO}_{3}\right)$ were estimated (based on known chemistry for proxy compounds) to allow estimation of the corresponding rate constants using the US EPA Estimation Program Interface Suite (USEPA, 2010), as well the structure activity relations described by Pfrang et al. (2006) and Kerdouci et al. (2010). Retention of the nitrate group upon reaction of the primary organic nitrates with $\mathrm{OH}$, $\mathrm{O}_{3}$, or $\mathrm{NO}_{3}$ was defined to occur $98 \%$ of the time for all BVOCs except isoprene, which was explicitly described, $\alpha$ phellandrene (defined as $49 \%$ based on structure estimation for reaction with $\mathrm{OH}$ or $\mathrm{O}_{3}$ ), and $\beta$-phellandrene (defined as $0 \%$ (complete loss) based on structure estimation for reaction with $\mathrm{OH}$ or $\mathrm{O}_{3}$ ). Secondary dinitrates were predicted to form based on organic nitrate yields, described above, for all BVOCs except $\alpha$-phellandrene (0.5 dinitrate yield assumed) and $\beta$-phellandrene (no dinitrate formation assumed). Nitrate structures were estimated based on trends in bond reactivity and previous studies of organic nitrate formation (Shepson, 2007). A goal of this study was to highlight potentially important BVOC-oxidant chemistry that should be studied further; therefore, the absolute concentrations of organic nitrates reflect the simulation assumptions and should be evaluated by further laboratory studies.

\subsubsection{Advection and dry deposition}

To examine the impact of local BVOC emissions and chemistry, the forest canopy was assumed to be the only source of BVOCs. BVOCs and reaction products were removed via horizontal advection $\left(H_{i}\right)$ from the above canopy bins based on horizontal loss rate constants $\left(k_{\text {wind }}\right)$ defined as:

$k_{\text {wind }}=\frac{U(z)}{30 \mathrm{~km}}$

$U(z)$ is the wind speed at a given altitude (in $\mathrm{km} \mathrm{s}^{-1}$ ). While there is heterogeneity in the forest canopy within
Table 3. Secondary isoprene nitrates and corresponding rate constants (units of $\mathrm{cm}^{3}$ molec $^{-1} \mathrm{~s}^{-1}$ ).

\begin{tabular}{|c|c|c|}
\hline $\begin{array}{l}\text { Isoprene } \\
\text { Nitrate }\end{array}$ & Structure & $\begin{array}{l}k_{\mathrm{OH}} k_{\mathrm{O} 3} k_{\mathrm{NO} 3} \\
\left(\mathrm{~cm}^{3} \mathrm{molec}^{-1} \mathrm{~s}^{-1}\right)\end{array}$ \\
\hline MACRN & & $\begin{array}{l}5.0 \times 10^{-11, a} \\
(<) 1 \times 10^{-20, b} \\
9.6 \times 10^{-16, c}\end{array}$ \\
\hline MVKN & & $\begin{array}{l}5.6 \times 10^{-12, \mathrm{a}} \\
(<) 1 \times 10^{-20, \mathrm{~b}} \\
4.7 \times 10^{-15, \mathrm{c}}\end{array}$ \\
\hline ETHLN & & $\begin{array}{l}1.0 \times 10^{-11, \mathrm{a}} \\
(<) 1 \times 10^{-20, \mathrm{~b}} \\
2.9 \times 10^{-16, \mathrm{c}}\end{array}$ \\
\hline PROPNN & & $\begin{array}{l}4.9 \times 10^{-13, a} \\
(<) 1 \times 10^{-20, b} \\
9.4 \times 10^{-16, c}\end{array}$ \\
\hline
\end{tabular}

a Paulot et al. (2009), ${ }^{\mathrm{b}}$ Atkinson et al. (1990), ${ }^{\mathrm{c}}$ Estimated based on Kerdouci et al. (2010).

and near UMBS (Bergen and Dronova, 2007), a homogeneous forest path length of $30 \mathrm{~km}$ is assumed, based on the approximate distance from UMBS to Lakes Huron and Michigan. Measurements of wind speeds at $46 \mathrm{~m}$ at the AmeriFlux tower using a Campbell Scientific CSAT3 sonic anemometer were used to derive friction velocities $\left(u_{*}\right)$; using Eq. (12), vertically-resolved wind speeds were calculated and are shown in Fig. S4.

$U(z)=\frac{u_{*}}{k} \ln \left(\frac{z-d}{z_{0}}\right)$

$d$ is the zero-plane displacement, defined as $0.75^{*}$ canopy height $(22.0 \mathrm{~m}), k$ is the von Karman constant $(0.40), z$ is the altitude of the bin mid-point, and $z_{0}$ is the aerodynamic surface roughness length $(2.0 \mathrm{~m})$, calculated based on the Monin-Obukhov length during neutral atmospheric stability conditions.

Reaction products were removed via dry deposition from the two canopy bins (starting at $12.1 \mathrm{~m}$ and $20.9 \mathrm{~m}$ above ground, respectively). Dry deposition loss $\left(D_{i}\right)$ was defined by the species specific deposition velocity $\left(v_{\mathrm{d}}\right)$ :

$D_{i}=\frac{v_{\mathrm{d}, i} \cdot\left[\mathrm{VOC}_{i}\right]}{z}$

Dry deposition velocities of organic nitrates are thought to range between that of peroxyacetyl nitrate (PAN, $0.5 \mathrm{~cm} \mathrm{~s}^{-1}$ ) and $\mathrm{HNO}_{3}\left(4-5 \mathrm{~cm} \mathrm{~s}^{-1}\right)$ (Grossenbacher et al., 2001). For a pine forest, Farmer and Cohen (2008) calculated a summer mid-day deposition velocity of $2.7 \mathrm{~cm} \mathrm{~s}^{-1}$ for total $\mathrm{RONO}_{2}$. Daytime dry deposition velocities $\left(v_{\mathrm{d}}\right)$ were assumed as follows: first-generation isoprene oxidation products, including MVK, MACR, and $\mathrm{C}_{5}$-unsaturated hydroxyaldehyde isomers, $\left(0.5 \mathrm{~cm} \mathrm{~s}^{-1}\right)$ (Zhang et al., 2003), primary 


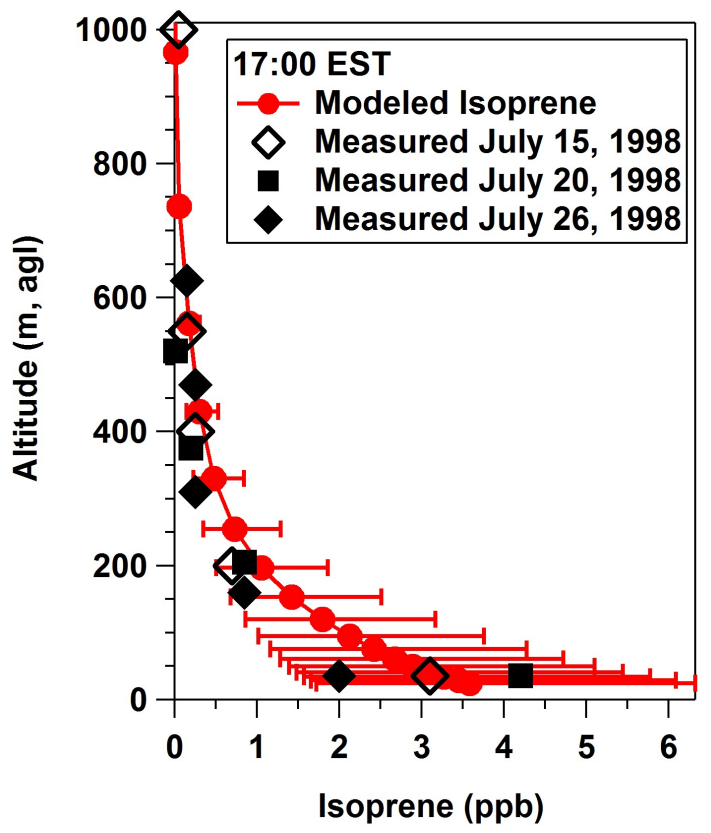

Fig. 1. Comparison of modeled and measured (Hurst et al., 2001) vertical profiles of isoprene concentrations at UMBS. Error bars represent sensitivity to the range of isoprene emission rates.

organic nitrates $\left(1.5 \mathrm{~cm} \mathrm{~s}^{-1}\right)$, and secondary organic nitrates $\left(2.5 \mathrm{~cm} \mathrm{~s}^{-1}\right)$. Nighttime dry deposition velocities were assumed to be $10 \%$ of daytime values, following Ganzeveld et al. (2008).

\section{Results and discussion}

\subsection{BVOC emissions and concentrations}

The predicted isoprene emission rate diurnal cycle (Fig. S5, mid-day average canopy top flux of 3.5 [1.16.2] $\mathrm{mg} \mathrm{C} \mathrm{m}^{-2} \mathrm{~h}^{-1}$ ) agrees well with previous eddy covariance measurements at UMBS with average mid-day fluxes of $2.8,3.2$, and $2.9 \mathrm{mg} \mathrm{C} \mathrm{m}^{-2} \mathrm{~h}^{-1}$ for the summers of 2000-2002 (Pressley et al., 2005). For the base production scenario, simulated isoprene emissions $\left(2.9 \times 10^{19}\right.$ molecules $\mathrm{m}^{-2} \mathrm{~h}^{-1}$ ) comprised $95 \%$ of all BVOCs emitted on a molar basis from the UMBS forest at the time of maximum total BVOC emissions (14:00) (Fig. S5). As shown in Fig. 1, the modeled isoprene vertical profile at 17:00 is in agreement with previous measurements made at UMBS at the same time of day (Hurst et al., 2001). In the daytime, the isoprene concentrations at $\sim 12 \mathrm{~m}$ above the forest canopy agree with measured values (Fig. 2), similar to previous modeling by Sillman et al. (2002). However, at night (22:00-06:00) modeled isoprene concentrations were lower than observed, with increasing biases through the night. Previous studies using a 0-D model found that the observed isoprene decay rate in the late evening at UMBS

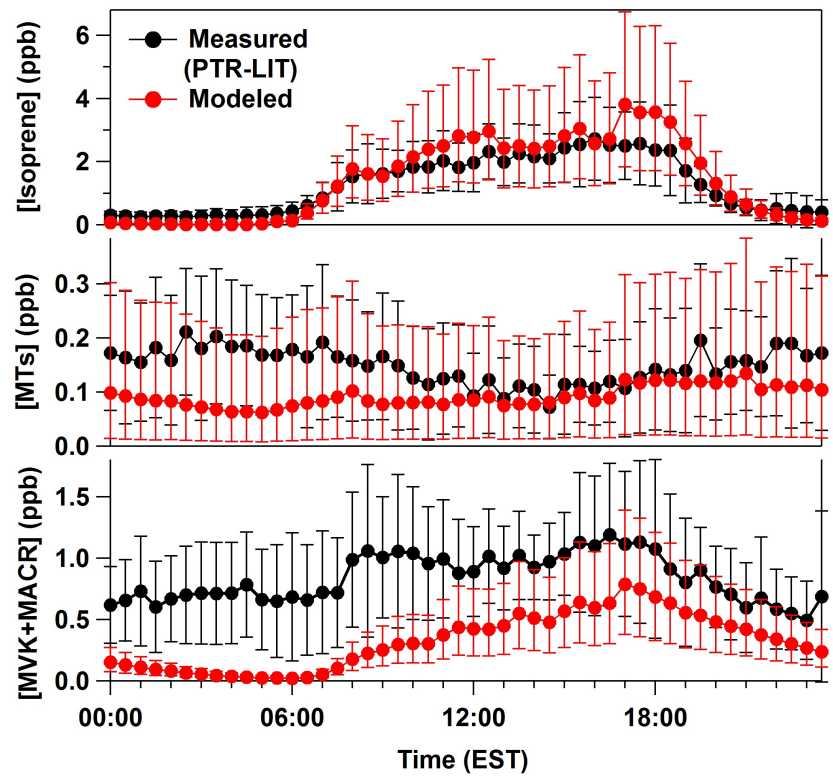

Fig. 2. Diurnal cycles of modeled and measured [isoprene], [total monoterpenes (MTs)], and [methyl vinyl ketone $(\mathrm{MVK})+$ methacrolein $(\mathrm{MACR})]$ at $\sim 12 \mathrm{~m}$ above the forest canopy. July-August 2008 measurements were completed using a proton-transfer reaction linear ion trap mass spectrometer (PTR-LIT) (Mielke et al., 2010). Sensitivity to uncertainties and variability are indicated by error bars.

was over-predicted, and they hypothesized that this was due to uncertainties in vertical mixing estimates and/or an unknown dark isoprene emission source (Hurst et al., 2001). Uncertainties associated with calculated $\mathrm{NO}_{3}$ radical concentrations cannot account for the isoprene concentrations (Hurst et al., 2001). Here we included a simple estimate of vertical mixing and found that isoprene concentrations were still under-predicted at night. This further suggests the presence of a nighttime isoprene emission source, estimated previously by Faloona et al. (2001) to be $\sim 2-30 \mu \mathrm{g} \mathrm{m}^{-2} \mathrm{~h}^{-1}$ in the summer at UMBS.

The discrepancy between measured and modeled isoprene concentrations at night is unlikely to be caused by overestimating $[\mathrm{OH}]$ because modeled concentrations of methyl vinyl ketone (MVK) and methacrolein (MACR) are also under-predicted at night (00:00-08:00) (Fig. 2). Additionally, the modeled ratios of [MVK+MACR]/[Isoprene] and $[\mathrm{MVK}] /[\mathrm{MACR}]$ agree with measurements (Fig. S6). The observed underprediction of daytime MVK and MACR concentrations is expected because we included only the oxidation of locally emitted BVOCs and did not advect BVOC oxidation products to the site. Here, a sensitivity study was performed to examine the impact of advection out of the model column on MVK and MACR. While decreasing advection of all species by half increased [MVK+MACR] by a factor of 2, these species were still under-predicted by the model in the morning, when isoprene concentrations were 
also under-predicted. However, rather than adding an advective source of MVK+MACR, we focus here on local organic nitrate formation from locally-emitted BVOCs. For this purpose, the measured and modeled BVOC concentrations were within the ranges of daytime variability overall. A detailed study of isoprene emission and oxidation in the nocturnal boundary layer should be completed to further our understanding of these processes, including the contributions from upwind advection.

At night, simulated MT and SQT emissions $(\sim 3-$ $4 \times 10^{17}$ molecules $\mathrm{m}^{-2} \mathrm{~h}^{-1}$ and $\sim 2-4 \times 10^{16}$ molecules $\mathrm{m}^{-2} \mathrm{~h}^{-1}$, respectively) comprised $\sim 79-82 \%$ and $\sim 7 \%$, respectively, of total BVOC emissions; the remaining minor fraction of emissions were due to other BVOCs, including oxygenated species, shown in Table S1. Modeled mid-day canopy-scale emission rates of total MTs and SQTs $\left(0.23[0.04-0.61] \mathrm{mg} \mathrm{m}^{-2} \mathrm{~h}^{-1}\right.$ and $0.03 \quad[0.001-0.09] \mathrm{mg} \mathrm{m}^{-2} \mathrm{~h}^{-1}$, respectively) were close to previous estimates $\left(0.21 \pm 0.06 \mathrm{mg} \mathrm{m}^{-2} \mathrm{~h}^{-1}\right.$ and $0.10 \pm 0.05 \mathrm{mg} \mathrm{m}^{-2} \mathrm{~h}^{-1}$, respectively) based on PTR-MS measurements at UMBS (Kim et al., 2009). Considering uncertainties and variability, modeled $\alpha$ - and $\beta$-pinene emission rates were also in agreement with measured fluxes at UMBS using a disjunct eddy accumulation system (Edwards et al., 2012); these new speciated MT flux measurements by Edwards et al. (2012) will help constrain emissions in future modeling efforts. Comparison between measured (PTR-LIT) and base modeled total MT concentrations ranged from agreement to an under-prediction of up to a factor of $\sim 3$; however, these values were still within the range of measured variability (Fig. 2).

\subsection{Biogenic organic nitrates and $\mathrm{NO}_{\mathrm{y}}$ budget}

Here we define total biogenic organic nitrates as the sum of primary and secondary biogenic organic nitrates, as well as nitrates formed from reaction of first generation isoprene oxidation products (MVK, MACR, IP-HMY, and IP-MHY). At $\sim 12 \mathrm{~m}$ above the forest canopy, the simulated concentration of total biogenic organic nitrates ranged from 12-74 ppt [4$137 \mathrm{ppt}$, considering emissions uncertainties and variability] through the day (Fig. 3). In the morning hours, enhanced vertical mixing led to increased simulated $\left[\mathrm{RONO}_{2}\right]$ aloft (shown for $\sim 560 \mathrm{~m}$ ).

For comparison, the measured $\mathrm{NO}_{\mathrm{y}}^{*}\left(\sim \mathrm{NO}_{\mathrm{y}}-\mathrm{HNO}_{3}\right)$ concentration at $\sim 12 \mathrm{~m}$ above the forest canopy ranged from $\sim$ $1.4-4.5 \mathrm{ppb}$ over the course of the average sunny day. Given these measurements, the simulations suggest that locallyproduced biogenic $\mathrm{RONO}_{2}$ contributed $\sim 1 \%$ (night) to $\sim$ $4 \%$ (day) of the measured $\mathrm{NO}_{\mathrm{y}}^{*}$ at $\sim 12 \mathrm{~m}$ above the forest canopy; considering the minimum and maximum emissions model scenarios, this range corresponds to $<1 \%$ to $\sim 8 \%$ of $\mathrm{NO}_{\mathrm{y}}^{*}$. During summertime aircraft-based measurements above the eastern United States, Perring et al. (2009a) observed $\sim 18 \%$ of $\mathrm{NO}_{\mathrm{y}}$ to be attributed to organic ni- trates when isoprene concentrations exceeded $500 \mathrm{ppt}$ in the boundary layer below $0.5 \mathrm{~km}$. Formaldehyde was correlated with the total organic nitrate concentrations, suggesting a major contribution from isoprene (Perring et al., 2009a). For UMBS, the contribution of isoprene-derived organic nitrates to the total simulated biogenic organic nitrates at $\sim 12 \mathrm{~m}$ above the forest canopy was predicted to reach a maximum of $\sim 89 \%$ in the afternoon (12:00-17:30) with a minimum of $\sim 20 \%$ in the early morning (05:00), when the contribution from monoterpenes reached its daily maximum $(\sim 70 \%)$. The calculated contribution of isoprene-derived organic nitrates to total biogenic organic nitrates was greater than $90 \%$ at all altitudes in the afternoon when vertical mixing and the isoprene nitrate production rate were highest. In the early morning, the fractional contribution of isoprene-derived organic nitrates was simulated to be $<40 \%$ below $\sim 150 \mathrm{~m}$, compared to $>90 \%$ above $\sim 1400 \mathrm{~m}$. This is due to the relatively greater emissions of monoterpenes at night compared to isoprene, resulting in monoterpene nitrate production in the near-canopy environment. These differences in the vertical profiles of the isoprene and monoterpene nitrates are clearly shown in Fig. 4. Simulated monoterpene nitrate concentrations below $\sim 500 \mathrm{~m}$ were higher at night than during the day due to nighttime monoterpene emissions and reaction with $\mathrm{NO}_{3}$. Above $\sim 500 \mathrm{~m}$, the monoterpene nitrate concentrations were lower at night than during the daytime due to decreased vertical mixing; however, we note uncertainties in the low nighttime mixing as K-theory does not capture nighttime turbulence events that have been observed in stable nocturnal boundary layers (e.g., Mahrt et al., 1998; Salmond and McKendry, 2005).

While simulated primary organic nitrate production at $\sim 12 \mathrm{~m}$ reached a maximum in the mid-day (17 times greater than nighttime production), the specific BVOCs and oxidants contributing to organic nitrate production changed with time of day, as shown in Fig. 5. At $\sim 12 \mathrm{~m}$ above the forest canopy at night, monoterpene- $\mathrm{NO}_{3}$ reactions comprised up to $83 \%$ of primary organic nitrate production, with isoprene- $\mathrm{OH}$ reactions comprising up to $82 \%$ during the daytime. At night, the major contributors $(>5 \%)$ to primary organic nitrate production were predicted to be limonene, $\gamma$-terpinene, $\alpha$ pinene, cis-ocimene, $\beta$-pinene, sabinene, $\beta$-myrcene, and $\alpha$ farnesene. Trans-ocimene, a light-dependent monoterpene, was estimated to be the greatest non-isoprene contributor to primary organic nitrate production (up to $\sim 10 \%$ ) during the day through reaction with $\mathrm{OH}$. It is quite noteworthy that during the day $(11: 00-17: 30), \sim 8 \%$ of the primary organic nitrate production was predicted to be from isoprene$\mathrm{NO}_{3}$ reactions due to high isoprene concentrations (modeled daytime average [isoprene] $=2.82 \mathrm{ppb}$; modeled daytime average $\left[\mathrm{NO}_{3}\right]=0.10 \mathrm{ppt}$ ). The $\mathrm{NO}_{3}$ lifetime versus photolysis was estimated to be $\sim 5 \mathrm{~s}$, compared to that for reaction with NO or isoprene of $\sim 18 \mathrm{~s}$ and $\sim 21 \mathrm{~s}$, respectively. Thus, while $\left[\mathrm{NO}_{3}\right]$ was lower in the daytime (by $\sim 4$ times on average compared to nighttime), isoprene concentrations were 


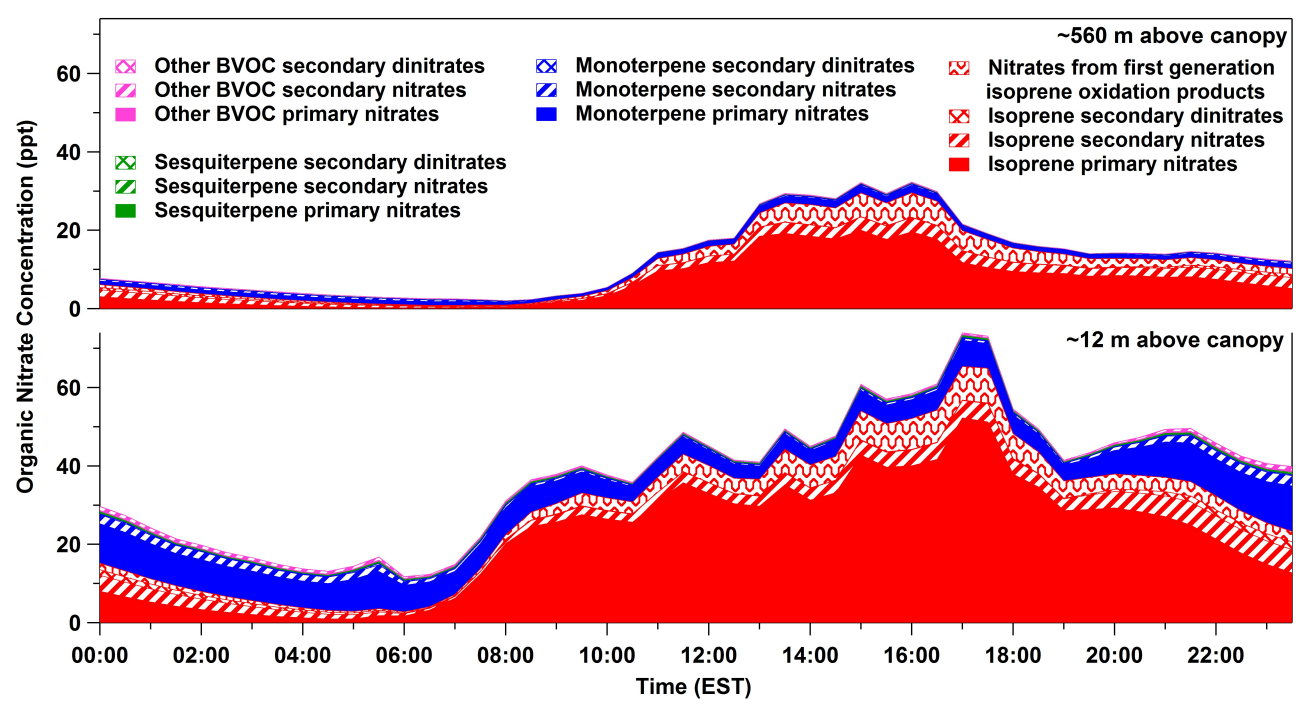

Fig. 3. Diurnal cycles of modeled organic nitrate concentrations at $\sim 560 \mathrm{~m}$ and $\sim 12 \mathrm{~m}$ above the forest canopy. Low total concentrations of sesquiterpene and other BVOC nitrates are shown for both heights, with concentrations ranging from $0.6 \mathrm{ppt}$ in the mid-day (12:30) to a maximum of $2.1 \mathrm{ppt}$ at 23:30 for $\sim 12 \mathrm{~m}$ above the forest canopy, compared to $0.1-0.4 \mathrm{ppt}$ through the course of the day at $\sim 560 \mathrm{~m}$ above the forest canopy. Results for the base BVOC production rate scenario are shown.

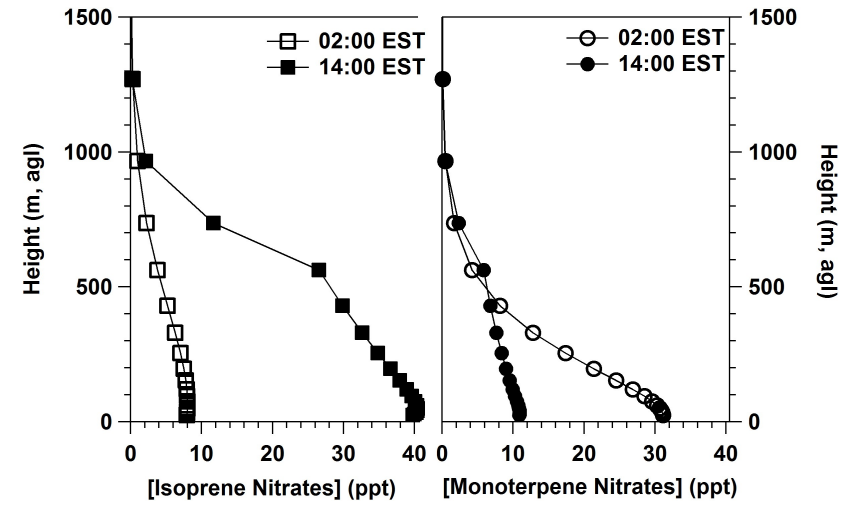

Fig. 4. Vertical profiles of total (primary and secondary) isoprene (left) and monoterpene (right) nitrate concentrations above the forest canopy at 02:00 and 14:00 EST. Total isoprene nitrates includes nitrates formed from first generation isoprene oxidation products (methacrolein, methyl vinyl ketone, and $\mathrm{C}_{5}$-unsaturated hydroxyaldehyde isomers). The base and maximum emission rate scenarios are shown for the isoprene nitrates and monoterpene nitrates, respectively.

much higher (by $\sim 45$ times (modeled)) in the daytime, so these are compensating effects. This led to a greater predicted rate of primary isoprene nitrate production via $\mathrm{NO}_{3}$ in the daytime (Fig. 6). Therefore, this analysis suggests that $\mathrm{NO}_{3}$-isoprene chemistry is an important daytime pathway at UMBS. Due to under-predicted isoprene concentrations at night (Sect. 3.1), isoprene nitrate production from $\mathrm{NO}_{3}$ chemistry at night was also likely under-predicted.

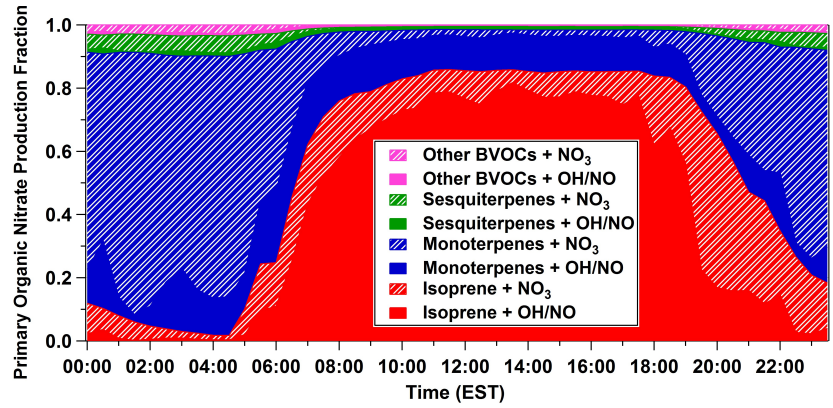

Fig. 5. Diurnal cycle of fractional modeled primary organic nitrate production at $\sim 12 \mathrm{~m}$ above the forest canopy. Results for the base BVOC production rate scenario are shown.

The $24 \mathrm{~h}$ total column simulated local biogenic $\mathrm{RONO}_{2}$ production rate was calculated to be 18 [836] $\mu \mathrm{mol} \mathrm{m}{ }^{-2} \mathrm{~d}^{-1}$. In comparison, soil measurements at UMBS showed an estimated source $\mathrm{NO}_{\mathrm{x}}$ flux of $4.3 \mu \mathrm{mol} \mathrm{m}^{-2} \mathrm{~d}^{-1}$ (Alaghmand et al., 2011), suggesting significant contribution of local organic nitrate formation from locally-emitted $\mathrm{NO}_{\mathrm{x}}$. Overall, dry deposition, horizontal advection, and chemical reaction accounted for $\sim 15 \%, \sim 52 \%$ and $\sim 32 \%$, respectively, of organic nitrate loss in the simulations (Fig. S7). The modeled organic nitrate dry deposition rate of $2.8[1.2-5.5] \mu \mathrm{mol} \mathrm{m}^{-2} \mathrm{~d}^{-1}$ is consistent with the previous estimate for organic nitrogen dry deposition $\left(2.0 \mu \mathrm{mol} \mathrm{m}{ }^{-2} \mathrm{~d}^{-1}, \sim 1 \%\right.$ of the total calculated nitrogen dry deposition) at UMBS by Hill et al. (2005). Given the significant uncertainty associated with the assumed dry deposition velocities, two sensitivity model 


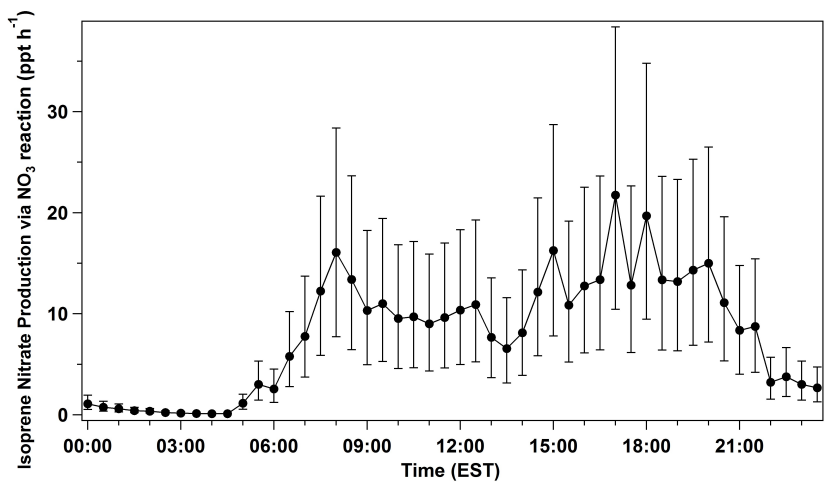

Fig. 6. Modeled diurnal cycle of primary isoprene nitrate production via reaction of $\mathrm{NO}_{3}$ with isoprene at $\sim 12 \mathrm{~m}$ above the forest canopy. Error bars represent sensitivity to emission rate uncertainties and variability.

runs were performed using either $0.5 \mathrm{~cm} \mathrm{~s}^{-1}$ or $2.5 \mathrm{~cm} \mathrm{~s}^{-1}$ for the deposition velocities of all oxidation products. Using a deposition velocity of $0.5 \mathrm{~cm} \mathrm{~s}^{-1}$, simulated $\left[\mathrm{RONO}_{2}\right]$ increased by $28 \%$ from the assumptions of the base case (see Sect. 2.2.5). In contrast, a deposition velocity of $2.5 \mathrm{~cm} \mathrm{~s}^{-1}$ resulted in decreased $[\mathrm{MVK}+\mathrm{MACR}]$ and $\left[\mathrm{RONO}_{2}\right]$ by $11 \%$ and $32 \%$, respectively.

In this model, horizontal advection also removed organic nitrates from the 1-D column; however, in the atmosphere, more extensive processing of the organic nitrates occurs as the air mass moves downwind of this BVOC source region. To evaluate the impact of continued oxidation for longer timescales in the downwind plume, a simulation was run with horizontal advection turned off and BVOC emissions only allowed during the first spin-up day in the model with evaluation of the second day. During the second simulation day, the concentration of total simulated biogenic organic nitrates, at $\sim 12 \mathrm{~m}$ above the forest canopy, declined by $\sim 92 \%$ with an increasing fraction of secondary organic nitrates (59\% to $90 \%$ of the total), showing the impact of reactions with $\mathrm{OH}$, $\mathrm{O}_{3}$, and $\mathrm{NO}_{3}$, as well as dry deposition. In particular, since most secondary isoprene nitrates release $\mathrm{NO}_{\mathrm{x}}$ upon subsequent reaction (Paulot et al., 2009), the total simulated concentration of isoprene nitrates decreased significantly during this time period, corresponding to a calculated increase in $\mathrm{NO}_{2}$ of $\sim 138$ ppt. This is equal to $\sim 11 \%$ of the daily average $\mathrm{NO}_{2}$ concentration at UMBS.

\subsection{Individual isoprene nitrates}

Recent laboratory studies by Paulot et al. (2009); Rollins et al. (2009); Lockwood et al. (2010); and Costa (2011) allowed the simulation of individual isoprene nitrate species, shown in Tables 2 and 3, formed via reaction of isoprene with $\mathrm{OH}$ or $\mathrm{NO}_{3}$. As shown in Fig. 7, total simulated isoprene nitrate concentrations at $\sim 12 \mathrm{~m}$ above the forest canopy ranged from $\sim 3$ [2-5] ppt (at 06:00) to $\sim 65[37-115] \mathrm{ppt}$ (at 17:00). In the mid-day at $\sim 12 \mathrm{~m}$ above the forest canopy, $\sim 91 \%$ of the primary isoprene nitrates were formed via $\mathrm{OH}$ oxidation, compared to $\sim 42 \%$ at night when $\mathrm{NO}_{3}$ oxidation was prevalent. Previously, Giacopelli et al. (2005), using a zero-dimensional model for UMBS that did not include $\mathrm{NO}_{3}$ chemistry, predicted a maximum afternoon isoprene nitrate concentration of $79 \mathrm{ppt}$, in agreement with our one-dimensional model simulations. The most abundant individual isoprene nitrate isomers, at $\sim 12 \mathrm{~m}$ above the forest canopy, in the daytime were predicted here to be $\mathrm{RONO}_{2}$ 4,3 , estimated to be present at concentrations up to 28 [13-49] ppt, and $\mathrm{RONO}_{2}-1,2$ (up to 10 [5-18] ppt) (Fig. 7, see Table 2 for structures); at their maximum concentrations at this height, these compounds comprised $\sim 60 \%$ and $\sim 22 \%$ of the primary isoprene nitrates produced via $\mathrm{OH}$ oxidation. These two primary isoprene nitrates are the most abundantly produced nitrates via $\mathrm{OH}$ oxidation at relative yields of $63.0 \%$ and $18.3 \%$, respectively, as observed by Costa (2011). The enrichment in $\mathrm{RONO}_{2}-1,2$ relative to its yield was due to lower predicted reaction rates with $\mathrm{OH}$ and $\mathrm{O}_{3}$ compared to $\mathrm{RONO}_{2}-4,3$ (Table 2). Through the night, the relative concentrations of the primary $\mathrm{OH}$-produced isoprene nitrates changed due to reaction with $\mathrm{NO}_{3} . \mathrm{RONO}_{2}-$ 1,2 , in particular, was significantly enriched at night compared to its relative production yield due to a lower predicted reaction (removal) rate with $\mathrm{NO}_{3}$, compared to the other nitrates (Table 2). During previous measurements at UMBS, Grossenbacher et al. (2001) and Giacopelli et al. (2005) detected two abundant gas chromatographic peaks associated with nitrates produced from the $\mathrm{OH}$-oxidation of isoprene, with associated average diurnal concentrations ranging from $\sim 1-10$ ppt and observations up to $\sim 90$ ppt. Figure 8 shows a comparison between the modeled concentrations of the two most abundant isoprene nitrate isomers $\left(\mathrm{RONO}_{2}-4,3\right.$ and $\left.\mathrm{RONO}_{2}-1,2\right)$ with the sum of the two most abundant isoprene nitrates measured by Giacopelli et al. (2005). Based on recent studies (Costa, 2011), we believe the gas chromatographic peaks correspond to the $\mathrm{RONO}_{2}-1,2$ and $\mathrm{RONO}_{2}-4,3$ species, eluting in that order; however, the ambient relative abundance of these two peaks was opposite of that predicted by the model, suggesting that future work needs to focus on understanding the removal processes of these isoprene nitrate species.

Reaction of primary isoprene nitrates with $\mathrm{OH}, \mathrm{O}_{3}$, or $\mathrm{NO}_{3}$ can produce secondary isoprene nitrates, as described by Giacopelli et al. (2005); Paulot et al. (2009); and Rollins et al. (2009) (Table 3); in addition, nitrates can form from subsequent oxidation of the first generation isoprene oxidation products, including MVK, MACR, and the $\mathrm{C}_{5}$-unsaturated hydroxyaldehyde isomers (Paulot et al., 2009; Costa, 2011). In general, the contributions of secondary isoprene nitrates and nitrates formed from first generation isoprene oxidation products were simulated to increase with altitude and time of day. Following initiation of isoprene emissions in the morning, primary isoprene nitrates contributed $\sim 90 \%$ of the total 


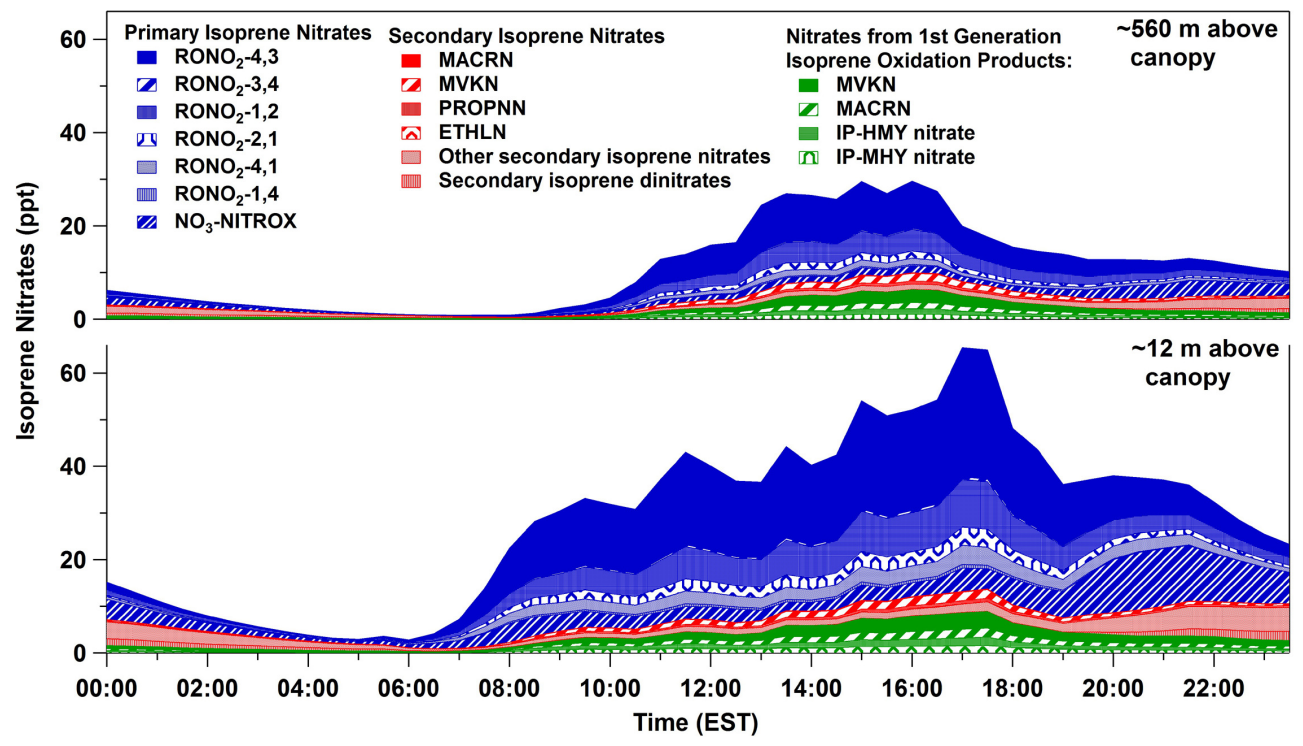

Fig. 7. Diurnal cycles of the modeled concentrations of isoprene nitrates at $\sim 12$ and $\sim 560 \mathrm{~m}$ above the forest canopy for the base isoprene production rate scenario. Structures of specific primary and secondary isoprene nitrates are shown in Tables 2 and 3.

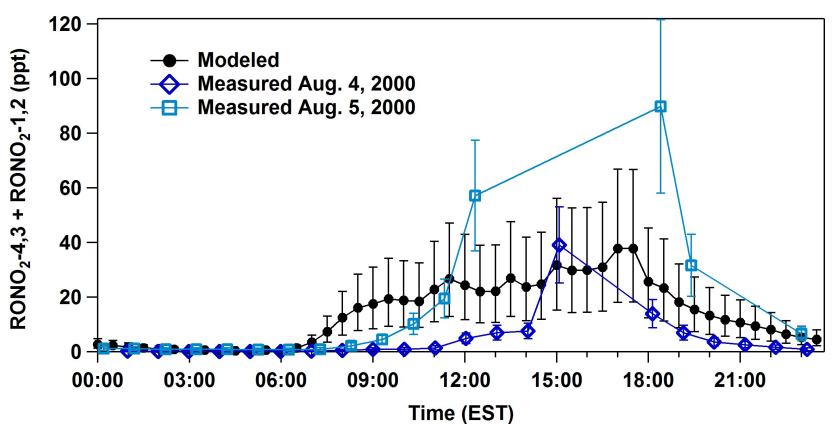

Fig. 8. Comparison of the sum of the concentrations of the two most abundant modeled ( $\sim 12 \mathrm{~m}$ above forest canopy) isoprene nitrate isomers $\left(\mathrm{RONO}_{2}-4,3\right.$ and $\left.\mathrm{RONO}_{2}-1,2\right)$ with the two most abundant isoprene nitrate isomers measured ( $\sim 10 \mathrm{~m}$ above the forest canopy) at UMBS (Ford, 2001; Giacopelli et al., 2005). Error bars for modeled concentrations represent sensitivity to the range of isoprene emission rates.

simulated concentration of isoprene nitrates (defined here as primary, secondary, and first generation oxidation product isoprene nitrates) at $\sim 12 \mathrm{~m}$ above the forest canopy (Fig. 7). Through the day and overnight, secondary isoprene nitrate concentrations increased due to reactions of first generation isoprene oxidation products and primary isoprene nitrates. By early morning, secondary isoprene nitrates were predicted to comprise $\sim 55 \%$ of the total simulated isoprene nitrate concentration at $\sim 12 \mathrm{~m}$ above the forest canopy. At the same time, the contribution of nitrates formed from the reaction of first generation isoprene oxidation products was estimated at $\sim 15 \%$; however, considering the under-prediction of MVK and MACR by the model, particularly in the early morning
(Fig. 2), this represents a lower limit for the concentration and contribution of these species.

\subsection{Monoterpene nitrates}

Monoterpenes accounted for $\sim 6 \%$ of the simulated BVOC emissions (on a molar basis) at UMBS. At night, simulated monoterpenes comprised $\sim 80-82 \%$ of the total BVOC emissions at UMBS (Fig. S5). The individual monoterpenes $\alpha$-pinene, limonene, $\beta$-pinene, $\gamma$-terpinene, $\beta$-myrcene, cisocimene, and sabinene each comprised $>5 \%$ of the nighttime total BVOC emissions. Unlike isoprene concentrations, which reached a maximum in the mid-day for $\sim 12 \mathrm{~m}$ above the forest canopy, the measured average total monoterpene concentration only varied by a factor of $\sim 2$ through the entire day (119-245 ppt) (Fig. 2). While significant uncertainties exist with respect to the $\mathrm{RONO}_{2}$ yields of numerous monoterpenes, as noted in Sect. 2.2.4, the trends in the simulated monoterpene nitrates can be examined (Fig. 9). In contrast to the diurnal cycle of isoprene nitrates (Fig. 7), the maximum concentration of primary and secondary monoterpene nitrates at $\sim 12 \mathrm{~m}$ above the forest canopy occurred at night due to the reaction of monoterpenes with $\mathrm{NO}_{3}$ (Fig. 9). While the base model scenario predicted a maximum total monoterpene nitrate concentration of $14 \mathrm{ppt}$, this scenario also underpredicted the total monoterpene concentration at night, compared to the PTR-LIT measurements (Fig. 2). Thus, the maximum total monoterpene nitrate concentration could reasonably be $\sim 40 \mathrm{ppt}$, as predicted by the maximum emissions scenario, which showed improved agreement with the total monoterpene concentration at night. Compared to isoprene, most monoterpenes are characterized by higher rate constants for reaction with $\mathrm{NO}_{3}$ and lower rate constants 


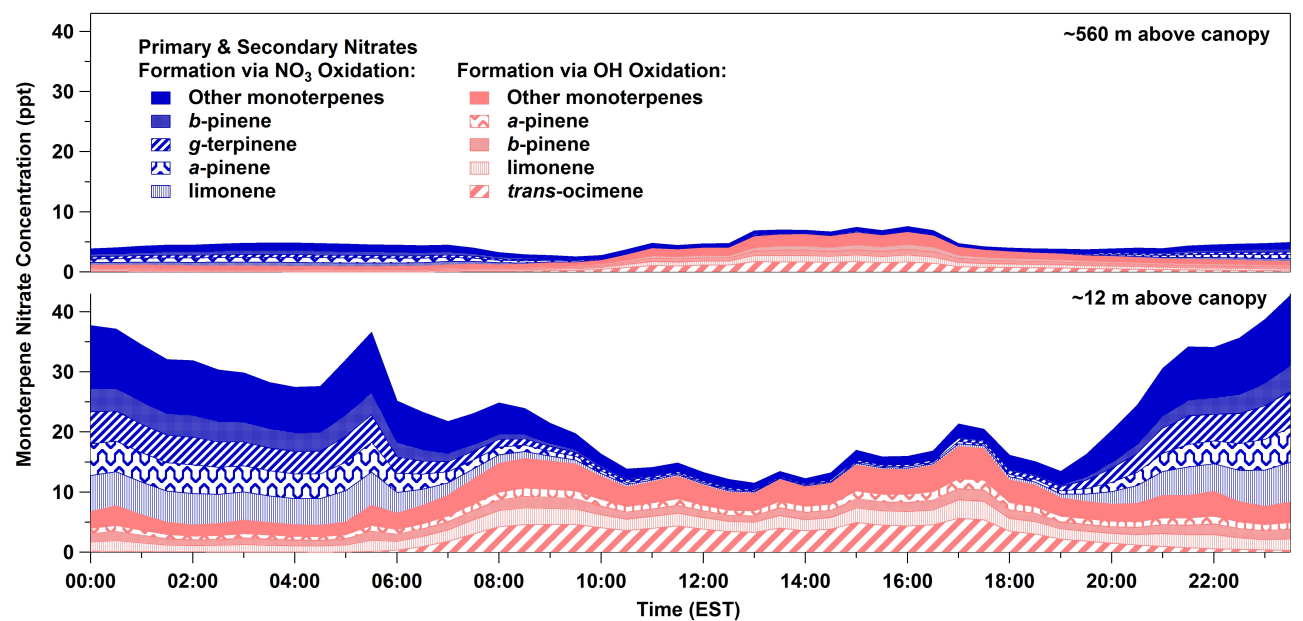

Fig. 9. Diurnal cycles of modeled monoterpene nitrate concentrations at $\sim 560 \mathrm{~m}$ and $\sim 12 \mathrm{~m}$ above the forest canopy. Both primary and secondary nitrates are shown, where the oxidant refers to the initial reaction. Results for the maximum BVOC production rate scenario are shown.

for reaction with $\mathrm{OH}$; when coupled with higher $\mathrm{RONO}_{2}$ yields for reaction with $\mathrm{NO}_{3}$ compared to $\mathrm{OH}$ (Tables 1 and $\mathrm{S} 1$ ), this results in the nighttime maximum for $\sim 12 \mathrm{~m}$ above the forest canopy. However, similar to isoprene, the concentration of monoterpene nitrates aloft was governed by vertical mixing with a maximum in the afternoon. As shown in Fig. 9, significant precursors to monoterpene nitrates included limonene (both $\mathrm{OH}$ and $\mathrm{NO}_{3}$ reactions), $\alpha$-pinene (both $\mathrm{OH}$ and $\mathrm{NO}_{3}$ reactions), $\gamma$-terpinene $\left(\mathrm{NO}_{3}\right.$ reaction), $\beta$-pinene (both $\mathrm{OH}$ and $\mathrm{NO}_{3}$ reactions), and trans-ocimene (OH reaction).

\subsection{Impacts of forest succession on BVOC emissions and organic nitrates}

A major fraction of the upper Great Lakes region forest consists of aspen trees (Populus grandidentata and Populus tremuloides), which grew following the harvest of mature forests in the late 19th and early 20th centuries (Friedman and Reich, 2005). Given the short lifetimes $(<100 \mathrm{yr})$ of aspen trees, the forest in northern Michigan is undergoing forest succession, where the aspen trees are currently being replaced by northern hardwoods (Acer rubrum, Acer saccharum, Fagus grandifola) and upland pine (Pinus strobus, Pinus resinosa) (Bergen and Dronova, 2007). Here, we simulated the effect of these future forest emissions on organic nitrate composition using current (summer 2008) temperatures. Two future forest composition scenarios were simulated with aspen being replaced by either northern hardwoods or upland pine (see supporting information for more detail).

At UMBS, isoprene is emitted primarily by aspen and red oak, such that loss of aspen trees decreased simulated isoprene emissions by $46-53 \%$ to a mid-day average flux of $1.1-1.3 \mathrm{mg} \mathrm{C} \mathrm{m}^{-2} \mathrm{~h}^{-1}\left(1.1-1.3 \times 10^{19}\right.$ molecules $\left.\mathrm{m}^{-2} \mathrm{~h}^{-1}\right)$. The replacement of the aspen by northern hardwoods and upland pine changed total monoterpene, sesquiterpene, and other BVOC emissions by factors of $0.7-1.5,1.5-1.8$, and 1.0-2.0, respectively. However, isoprene emissions were predicted to still comprise $83-89 \%$ of the total BVOC emissions at UMBS (compared to the current 93\%). The speciated composition of the BVOC emissions was also predicted to change (Fig. S8), where replacement of aspen with either northern hardwoods or upland pines increased several sesquiterpenes $(\alpha$-cedrene, $\alpha$-muurolene, $\gamma$-muurolene, $\gamma$-cadinene, $\beta$-bisabolene $\beta$-farnesene, and $\alpha$-humulene) by factors of more than 10; replacement with northern hardwoods was also predicted to increase emission rates of certain monoterpenes (4-carene, $p$-cymenene, and cyclofenchone) and oxygenated BVOCs (1,8-cineole, cis-linalool oxide, trans-linalool oxide, camphene, and borneol) by factors of more than 10 . Under both northern hardwood and upland pine future forest scenarios, $\alpha$-pinene, $\beta$-pinene, limonene, and $\beta$-myrcene were predicted to each contribute greater than $5 \%$ to the total BVOC emissions at night.

Isoprene was predicted to reach an afternoon maximum concentration of $\sim 2 \mathrm{ppb}$ at $\sim 12 \mathrm{~m}$ above the forest canopy, compared to current predicted maximum of $\sim 3.6 \mathrm{ppb}$ (base emission scenarios). Average daily total monoterpene, sesquiterpene, and other BVOC concentrations, at $\sim 12 \mathrm{~m}$ above the forest canopy, ranged from approximately $89-153,8-9$, and $23-40 \mathrm{ppt}$, respectively (compared to $\sim 92,5$, and $19 \mathrm{ppt}$, respectively, for the current simulations). Due to the reduced isoprene concentrations, and therefore reduced total BVOC concentrations, the total biogenic organic nitrate concentration was predicted to decrease in the afternoon by $35-40 \%$ at $\sim 12 \mathrm{~m}$ above the forest canopy (Fig. S9). While isoprene nitrate concentrations were predicted to decrease by $\sim 46 \%$, the concentrations of organic nitrate derived from monoterpenes, sesquiterpenes, 
and other BVOCs increased in the late afternoon by factors of $\sim 4-5,2-3,6-11$, respectively. These are likely lower limit changes for the monoterpenes and their oxidation products, as it does not take into account other climate changes, such as increasing ambient temperatures and elevated $\mathrm{CO}_{2}$ (Peñuelas and Staudt, 2010).

\section{Conclusions}

The fate of the 57 individual BVOCs locally emitted from the mixed forest in northern Michigan and their role in organic nitrate formation in the lower troposphere was investigated. In order to obtain a first estimate of detailed organic nitrate formation from speciated compounds, atmospheric processes were simplified. BVOC emission rates are difficult to determine due to tree-to-tree variability and sampling challenges during branch enclosure BVOC emission measurements (e.g., Ortega et al., 2008), leading to large ranges in estimated production rates, shown here to result in a range of oxidation product concentrations. In the future, improved canopy-level flux measurements of speciated monoterpenes, such as those recently completed by Edwards et al. (2012) at UMBS, will improve modeling of individual monoterpenes at the canopy level.

During the daytime at $\sim 12 \mathrm{~m}$ above the forest canopy, simulated isoprene-OH reactions comprised up to $82 \%$ of simulated primary organic nitrate production. In the afternoon, when vertical mixing and isoprene nitrate production were highest, the simulated contribution of isoprene-derived organic nitrates was greater than $90 \%$ at all altitudes, with the concentration of secondary isoprene nitrates increasing with altitude. In addition, $\mathrm{NO}_{3}$ reactions led to a high simulated fractions of primary isoprene nitrates, ranging from $\sim 9 \%$ during mid-day at $\sim 12 \mathrm{~m}$ above the forest canopy to $\sim 58 \%$ at night; thus, the individual products and fates of isoprene- $\mathrm{NO}_{3}$ reactions need to be studied in detail to expand upon the work of Perring et al. (2009b) and Rollins et al. (2009) and improve our understanding of this pathway. In general, the contributions of secondary isoprene nitrates and nitrates formed from first generation isoprene oxidation products increased with altitude and time of day; however, the formation and removal of these species are poorly understood due to few studies and should be the focus of future laboratory investigations.

At $\sim 12 \mathrm{~m}$ above the forest canopy, simulated monoterpene- $\mathrm{NO}_{3}$ reactions comprised up to $\sim 83 \%$ of primary organic nitrate production at night, resulting in major contributions to the total simulated biogenic $\mathrm{RONO}_{2}$ in the early morning. In particular, the formation of organic nitrates from reactions of $\gamma$-terpinene, limonene, $\alpha$-pinene, cis-ocimene, sabinene, $\beta$-pinene, and isoprene with $\mathrm{NO}_{3}$ each contributed greater than $5 \%$ to the total simulated biogenic organic nitrate production at night. However, the organic nitrate yields for reactions of $\mathrm{NO}_{3}$ with many sig- nificant BVOC precursors, including $\gamma$-terpinene, sabinene, cis-ocimene, $\alpha$-thujene, and $\beta$-myrcene, have not been measured, lending uncertainty to the simulations. Also, the rate constants corresponding to the reactions of $\alpha$-thujene and $\alpha$-farnesene with $\mathrm{NO}_{3}$ have not been measured, and these reactions are estimated to contribute up to $\sim 3 \%$ and $\sim 5 \%$, respectively, of primary organic nitrate production each at night at $\sim 12 \mathrm{~m}$ above the forest canopy. Likewise, the $\mathrm{NO}_{3}$ reaction rate constants have not been measured for most sesquiterpenes and oxygenated BVOCs emitted at UMBS. The contribution of $\mathrm{NO}_{3}$ reactions to the formation of isoprene nitrates and terpene nitrates is expected to be even greater in the southeastern United States, which is impacted by higher BVOC emissions and higher $\mathrm{NO}_{\mathrm{x}}$ concentrations, similar to the observations for $\mathrm{OH}$-produced isoprene nitrates (Grossenbacher et al., 2004). In addition, laboratory experiments should focus on detailed studies of organic nitrates formed via reactions of limonene with $\mathrm{NO}_{3}, \gamma$-terpinene with $\mathrm{NO}_{3}$, and trans-ocimene with $\mathrm{OH}$ given their predicted significant contribution to total organic nitrates. Further, forest succession was predicted to lead to significantly increased afternoon concentrations of monoterpene-derived organic nitrates, underscoring the need to better understand the formation and fate of these species, which can lead to secondary organic aerosol formation (e.g., Fry et al., 2009, 2011; Rollins et al., 2009).

Organic nitrates serve as reservoirs of $\mathrm{NO}_{\mathrm{x}}$, impacting ozone production (both locally and downwind), the oxidative capacity of the atmosphere (impacting trace gas removal and secondary organic aerosol formation and processing), and nitrogen availability to ecosystems. Since horizontal advection accounted for $\sim 52 \%$ of nitrate loss in the simulations, the local formation of biogenic $\mathrm{RONO}_{2}$ is expected to impact downwind atmospheric chemistry and deposition processes; estimates suggested significant $\mathrm{NO}_{2}$ release downwind, due to decreases in isoprene nitrate concentrations alone over the course of one day of transport. The relative concentrations of $\mathrm{OH}-$ produced primary isoprene nitrates changed significantly at night depending on their removal rates via reaction with $\mathrm{NO}_{3}$, the rate constants for which were calculated to span a large range, from $4.56 \times 10^{-14}$ to $4.81 \times 10^{-12} \mathrm{~cm}^{3} \mathrm{molec}^{-1} \mathrm{~s}^{-1}$ (Pfrang et al., 2006). These rate constants need to be measured to verify and improve the prediction of this nighttime removal. Since the speciated isoprene nitrates have been measured in the laboratory, and in some cases in the field, it should be possible to achieve closure on the total $\mathrm{RONO}_{2}$ budget at this isoprene-dominated site, given the major contributions of isoprene nitrates to the total simulated biogenic $\left[\mathrm{RONO}_{2}\right]$ at UMBS. Given the relatively low measured $\mathrm{NO}_{\mathrm{x}}$ conditions at UMBS (average $[\mathrm{NO}]=67 \mathrm{ppt}$; average $\left[\mathrm{NO}_{2}\right]=1.2 \mathrm{ppb}$ ), and therefore low propensity toward organic nitrate formation, the formation and downwind transport of biogenic organic nitrates formed in areas of higher $\mathrm{NO}_{\mathrm{x}}$ emissions (e.g., 
southeastern United States (Fiore et al., 2005)) are expected to significantly impact downwind atmospheric composition.

\section{Supplementary material related to this article is available online at: http://www.atmos-chem-phys.net/12/ 10125/2012/acp-12-10125-2012-supplement.pdf.}

Acknowledgements. Funding was provided by the National Science Foundation (AGS-0904151 and AGS-0542701) and Environmental Protection Agency (STAR grant R833750). K. A. Pratt gratefully acknowledges a NOAA climate and global change postdoctoral fellowship, administered by UCAR. L. H. Mielke acknowledges a NSF-IGERT fellowship for biosphere/atmosphere research training. M. A. Carroll (University of Michigan) and S. Bertman (Western Michigan University) are thanked for temperature and ozone data. J. Fuentes (Pennsylvania State University) is acknowledged for discussions. P. Giacopelli (Purdue University; currently Nutra Manufacturing, Inc.) is thanked for PROPHET 2000 isoprene nitrate data. This is publication \#1143 of the Purdue Climate Change Research Center.

Edited by: A. Hofzumahaus

\section{References}

Alaghmand, M., Shepson, P. B., Starn, T. K., Jobson, B. T., Wallace, H. W., Carroll, M. A., Bertman, S. B., Lamb, B., Edburg, S. L., Zhou, X., Apel, E., Riemer, D., Stevens, P., and Keutsch, F.: The Morning $\mathrm{NO}_{\mathrm{x}}$ maximum in the forest atmosphere boundary layer, Atmos. Chem. Phys. Discuss., 11, 2925129282, doi:10.5194/acpd-11-29251-2011, 2011.

Arey, J., Aschmann, S. M., Kwok, E. S. C., and Atkinson, R.: Alkyl nitrate, hydroxy nitrate, and hydroxycarbonyl formation from the $\mathrm{NO}_{\mathrm{x}}$-air photooxidations of $\mathrm{C}_{5}-\mathrm{C}_{8} n$-alkanes, J. Phys. Chem. A, 105, 1020-1027, 2001.

Atkinson, R., Hasegawa, J., and Aschmann, S. M.: Rate constants for the gas-phase reactions of $\mathrm{O}_{3}$ with a series of monoterpenes and related compounds at $296 \pm 2 \mathrm{~K}$, Int. J. Chem. Kinet., 22, 871-887, 1990.

Atkinson, R. and Arey, J.: Gas-phase tropospheric chemistry of biogenic volatile organic compounds: a review, Atmos. Environ., 37, S197-S219, 2003a.

Atkinson, R. and Arey, J.: Atmospheric degradation of volatile organic compounds, Chem. Rev., 103, 4605-4638, 2003b.

Atkinson, R., Baulch, D. L., Cox, R. A., Crowley, J. N., Hampson, R. F., Hynes, R. G., Jenkin, M. E., Rossi, M. J., Troe, J., and IUPAC Subcommittee: Evaluated kinetic and photochemical data for atmospheric chemistry: Volume II - gas phase reactions of organic species, Atmos. Chem. Phys., 6, 3625-4055, doi:10.5194/acp-6-3625-2006, 2006.

Barket, D. J., Grossenbacher, J. W., Hurst, J. M., Shepson, P. B., Olszyna, K., Thornberry, T., Carroll, M. A., Roberts, J., Stroud, C., Bottenheim, J., and Biesenthal, T.: A study of the $\mathrm{NO}_{\mathrm{x}}$ dependence of isoprene oxidation, J. Geophys. Res., 109, D11310, doi:10.1029/2003JD003965, 2004.

Beaver, M. R., Clair, J. M. St., Paulot, F., Spencer, K. M., Crounse, J. D., LaFranchi, B. W., Min, K. E., Pusede, S. E., Wooldridge, P.
J., Schade, G. W., Park, C., Cohen, R. C., and Wennberg, P. O.: Importance of biogenic precursors to the budget of organic nitrates: observations of multifunctional organic nitrates by CIMS and TD-LIF during BEARPEX 2009, Atmos. Chem. Phys., 12, 5773-5785, doi:10.5194/acp-12-5773-2012, 2012.

Bergen, K. M. and Dronova, I.: Observing succession on aspendominated landscapes using a remote sensing-ecosystem approach, Landscape Ecol., 22, 1395-1410, 2007.

Bollinger, M. J., Sievers, R. E., Fahey, D. W., and Fehsenfeld, F. C.: Conversion of nitrogen dioxide, nitric acid, and $n$-propyl nitrate to nitric oxide by gold-catalyzed reduction with carbon monoxide, Anal. Chem., 55, 1980-1986, 1983.

Bouvier-Brown, N. C., Goldstein, A. H., Gilman, J. B., Kuster, W. C., and de Gouw, J. A.: In-situ ambient quantification of monoterpenes, sesquiterpenes, and related oxygenated compounds during BEARPEX 2007: implications for gas- and particle-phase chemistry, Atmos. Chem. Phys., 9, 5505-5518, doi:10.5194/acp-9-5505-2009, 2009.

Boy, M., Sogachev, A., Lauros, J., Zhou, L., Guenther, A., and Smolander, S.: SOSA - a new model to simulate the concentrations of organic vapours and sulphuric acid inside the ABL Part 1: Model description and initial evaluation, Atmos. Chem. Phys., 11, 43-51, doi:10.5194/acp-11-43-2011, 2011.

Brown, S. S., deGouw, J. A., Warneke, C., Ryerson, T. B., Dubé, W. P., Atlas, E., Weber, R. J., Peltier, R. E., Neuman, J. A., Roberts, J. M., Swanson, A., Flocke, F., McKeen, S. A., Brioude, J., Sommariva, R., Trainer, M., Fehsenfeld, F. C., and Ravishankara, A. R.: Nocturnal isoprene oxidation over the Northeast United States in summer and its impact on reactive nitrogen partitioning and secondary organic aerosol, Atmos. Chem. Phys., 9, 30273042, doi:10.5194/acp-9-3027-2009, 2009.

Bryan, A. M., Bertman, S. B., Carroll, M. A., Dusanter, S., Edwards, G. D., Forkel, R., Griffith, S., Guenther, A. B., Hansen, R. F., Helmig, D., Jobson, B. T., Keutsch, F. N., Lefer, B. L., Pressley, S. N., Shepson, P. B., Stevens, P. S., and Steiner, A. L.: Incanopy gas-phase chemistry during CABINEX 2009: sensitivity of a 1-D canopy model to vertical mixing and isoprene chemistry, Atmos. Chem. Phys., 12, 8829-8849, doi:10.5194/acp-12-88292012, 2012.

Carroll, M. A., Bertman, S. B., and Shepson, P. B.: Overview of the Program for Research on Oxidants: PHotochemistry, Emissions, and Transport (PROPHET) summer 1998 measurements intensive, J. Geophys. Res., 106, 24275-24288, 2001.

Carter, W. P. L. and Atkinson, R.: Development and evaluation of a detailed mechanism for the atmospheric reactions of isoprene and $\mathrm{NO}_{\mathrm{x}}$, Int. J. Chem. Kinet., 28, 497-530, 1996.

Chen, X., Hulbert, D., and Shepson, P. B.: Measurement of the organic nitrate yield from $\mathrm{OH}$ reaction with isoprene, J. Geophys. Res., 103, 25563-25568, 1998.

Chuong, B. and Stevens, P. S.: Measurements of the kinetics of the OH-initiated oxidation of isoprene, J. Geophys. Res., 107, 4162, doi:10.1029/2001JD000865, 2002.

Costa, A. W.: Coupling between the carbon and nitrogen cycles in a forested environment, Ph.D., Chemistry, Purdue University, West Lafayette, IN, 279 pp., 2011.

Davis, M. E., Tapscott, C., and Stevens, P. S.: Measurements of the kinetics of the $\mathrm{OH}$-initiated oxidation of $\beta$-pinene: Radical propogation in the $\mathrm{OH}+\beta$-pinene $+\mathrm{O}_{2}+\mathrm{NO}$ reaction system, Int. J. Chem. Kinet., 37, 522-531, 2005. 
Day, D. A., Wooldridge, P. J., Dillon, M. B., Thornton, J. A., and Cohen, R. C.: A thermal dissociation laser-induced fluorescence instrument for in situ detection of $\mathrm{NO}_{2}$, peroxy nitrates, alkyl nitrates, and $\mathrm{HNO}_{3}$, J. Geophys. Res., 107, 4046, doi:10.1029/2001JD000779, 2002.

Day, D. A., Dillon, M. B., Wooldridge, P. J., Thornton, J. A., Rosen, R. S., Wood, E. C., and Cohen, R. C.: On alkyl nitrates, $\mathrm{O}_{3}$, and the "missing $\mathrm{NO}_{\mathrm{y}}$ ", J. Geophys. Res., 108, 4501, doi:10.1029/2003JD003685, 2003.

Dusanter, S., Vimal, D., Stevens, P. S., Volkamer, R., and Molina, L. T.: Measurements of $\mathrm{OH}$ and $\mathrm{HO}_{2}$ concentrations during the MCMA-2006 field campaign - Part 1: Deployment of the Indiana University laser-induced fluorescence instrument, Atmos. Chem. Phys., 9, 1665-1685, doi:10.5194/acp-9-1665-2009, 2009.

Edwards, G. D., Martins, D. K., Starn, T., Pratt, K., and Shepson, P. B.: A disjunct eddy accumulation system for the measurement of BVOC fluxes: instrument characterizations and field deployment, Atmos. Meas. Tech., 5, 2115-2132, doi:10.5194/amt-52115-2012, 2012.

Espada, C. and Shepson, P. B.: The production of organic nitrates from atmospheric oxidation of ethers and glycol ethers, Int. J. Chem. Kinet., 37, 686-699, 2005.

Faloona, I., Tan, D., Brune, W., Hurst, J., Barket, D., Couch, T. L., Shepson, P., Apel, E., Riemer, D., Thornberry, T., Carroll, M. A., Sillman, S., Keeler, G. J., Sagady, J., Hooper, D., and Paterson, K.: Nighttime observations of anomalously high levels of hydroxyl radicals above a deciduous forest canopy, J. Geophys. Res., 106, 24315-24333, 2001.

Farmer, D. K. and Cohen, R. C.: Observations of $\mathrm{HNO}_{3}, \Sigma \mathrm{AN}$, $\Sigma \mathrm{PN}$ and $\mathrm{NO}_{2}$ fluxes: evidence for rapid $\mathrm{HO}_{\mathrm{x}}$ chemistry within a pine forest canopy, Atmos. Chem. Phys., 8, 3899-3917, doi:10.5194/acp-8-3899-2008, 2008.

Farmer, D. K., Perring, A. E., Wooldridge, P. J., Blake, D. R., Baker, A., Meinardi, S., Huey, L. G., Tanner, D., Vargas, O., and Cohen, R. C.: Impact of organic nitrates on urban ozone production, Atmos. Chem. Phys., 11, 4085-4094, doi:10.5194/acp-11-40852011, 2011.

Fiore, A. M., Horowitz, L. W., Purves, D. W., Levy, H., Evans, M. J., Wang, Y., Li, Q., and Yantosca, R. M.: Evaluating the contribution of changes in isoprene emissions to surface ozone trends over the eastern United States, J. Geophys. Res., 110, D12303, doi:10.1029/2004JD005485, 2005.

Ford, K. M.: The study of organic nitrates in the field and in the laboratory, M.S., Purdue University, West Lafayette, IN, 85 pp., 2001.

Forkel, R., Siedl, W., Dlugi, R., and Deigele, E.: A one-dimensional numerical model to simulate formation and balance of sulfate during radiation fog events, J. Geophys. Res., 95, 18501-18515, 1990.

Forkel, R., Klemm, O., Graus, M., Rappenglück, B., Stockwell, W. R., Grabmer, W., Held, A., Hansel, A., and Steinbrecher, R.: Trace gas exchange and gas phase chemistry in a Norway spruce forest: A study with a coupled 1-dimensional canopy atmospheric chemistry emission model, Atmos. Environ., 40, 28 42, 2006.

Friedman, S. K. and Reich, P. B.: Regional legacies of logging: departure from presettlement forest conditions in northern Minnesota, Ecol. Appl., 15, 726-744, 2005.
Fry, J. L., Kiendler-Scharr, A., Rollins, A. W., Wooldridge, P. J., Brown, S. S., Fuchs, H., Dubé, W., Mensah, A., dal Maso, M., Tillmann, R., Dorn, H.-P., Brauers, T., and Cohen, R. C.: Organic nitrate and secondary organic aerosol yield from $\mathrm{NO}_{3}$ oxidation of $\beta$-pinene evaluated using a gas-phase kinetics/aerosol partitioning model, Atmos. Chem. Phys., 9, 14311449, doi:10.5194/acp-9-1431-2009, 2009.

Fry, J. L., Kiendler-Scharr, A., Rollins, A. W., Brauers, T., Brown, S. S., Dorn, H.-P., Dubé, W. P., Fuchs, H., Mensah, A., Rohrer, F., Tillmann, R., Wahner, A., Wooldridge, P. J., and Cohen, R. C.: SOA from limonene: role of $\mathrm{NO}_{3}$ in its generation and degradation, Atmos. Chem. Phys., 11, 3879-3894, doi:10.5194/acp-113879-2011, 2011.

Fuchs, H., Bohn, B., Hofzumahaus, A., Holland, F., Lu, K. D., Nehr, S., Rohrer, F., and Wahner, A.: Detection of $\mathrm{HO}_{2}$ by laserinduced fluorescence: calibration and interferences from $\mathrm{RO}_{2}$ radicals, Atmos. Meas. Tech., 4, 1209-1225, doi:10.5194/amt4-1209-2011, 2011.

Ganzeveld, L., Eerdekens, G., Feig, G., Fischer, H., Harder, H., Königstedt, R., Kubistin, D., Martinez, M., Meixner, F. X., Scheeren, H. A., Sinha, V., Taraborrelli, D., Williams, J., VilàGuerau de Arellano, J., and Lelieveld, J.: Surface and boundary layer exchanges of volatile organic compounds, nitrogen oxides and ozone during the GABRIEL campaign, Atmos. Chem. Phys., 8, 6223-6243, doi:10.5194/acp-8-6223-2008, 2008.

Gao, W., Wesely, M. L., and Dosky, P. V.: Numerical modeling of the turbulent-diffusion and chemistry of $\mathrm{NO}_{x}, \mathrm{O}_{3}$, isoprene, and other reactive trace gases in and above a forest canopy, J. Geophys. Res., 98, 18339-18353, 1993.

Geyer, A. and Stutz, J.: Vertical profiles of $\mathrm{NO}_{3}, \mathrm{~N}_{2} \mathrm{O}_{5}, \mathrm{O}_{3}$, and $\mathrm{NO}_{\mathrm{X}}$ in the noctural boundary layer: 2 . Model studies on the altitude dependence of composition and chemistry, J. Geophys. Res., 109, D12307, doi:10.1029/2003JD004211, 2004a.

Geyer, A. and Stutz, J.: The vertical structure of $\mathrm{OH}-$ $\mathrm{HO}_{2}-\mathrm{RO}_{2}$ chemistry in the noctural boundary layer: A one-dimensional study, J. Geophys. Res., 109, D16301, doi:10.1029/2003JD004425, 2004b.

Giacopelli, P., Ford, K., Espada, C., and Shepson, P. B.: Comparison of the measured and simulated isoprene nitrate distributions above a forest canopy, J. Geophys. Res., 110, D01304, doi:10.1029/2004JD005123, 2005.

Goldstein, A. H. and Galbally, I. E.: Known and unexplored organic constituents in the Earth's atmosphere, Environ. Sci. Technol., 41, 1514-1521, 2007.

Grossenbacher, J. W., Couch, T., Shepson, P. B., Thornberry, T., Witmer-Rich, M., Carroll, M. A., Faloona, I., Tan, D., Brune, W., Ostling, K., and Bertman, S.: Measurements of isoprene nitrates above a forest canopy, J. Geophys. Res., 106, 24429-24438, 2001.

Grossenbacher, J. W., Barket, D. J., Shepson, P. B., Carroll, M. A., Olszyna, K., and Apel, E.: A comparison of isoprene nitrate concentrations at two forest-impacted sites, J. Geophys. Res., 109, D11311, doi:10.1029/2003JD003966, 2004.

Guenther, A., Hewitt, C. N., Erickson, D., Fall, R., Geron, C., Graedel, T., Harley, P., Klinger, L., Lerdau, M., McKay, W. A., Pierce, T., Scholes, B., Steinbrecher, R., Tallamraju, R., Taylor, J., and Zimmerman, P.: A global model of natural volatile organic compound emissions, J. Geophys. Res., 100, 8873-8892, 1995. 
Guenther, A. B., Monson, R. K., and Fall, R.: Isoprene and monoterpene emission rate variability: Observations with eucalyptus and emission rate algorithm development, J. Geophys. Res., 96, 10799-10808, 1991.

Guenther, A. B., Zimmerman, P. R., Harley, P. C., Monson, R. K., and Fall, R.: Isoprene and monoterpene emission rate variability: Model evaluations and sensitivity analyses, J. Geophys. Res., 98, 12609-12617, 1993.

Guenther, A., Baugh, B., Brasseur, G., Greenberg, J., Harley, P., Klinger, L., Serça, D., and Vierling, L.: Isoprene emission estimates and uncertainties for the Central African EXPRESSO study domain, J. Geophys. Res., 104, 30625-30639, 1999.

Hallquist, M., Wängberg, I., Ljungström, E., Barnes, I., and Becker, K.-H.: Aerosol and product yields from $\mathrm{NO}_{3}$ radical-initiated oxidation of selected monoterpenes, Environ. Sci. Technol., 33, 553-559, 1999.

Hauglustaine, D. A., Madronich, S., Ridley, B. A., Walega, J. G., Cantrell, C. A., Shetter, R. E., and Hübler, G.: Observed and model-calculated photostationary state at Mauna Loa Observatory during MLOPEX 2, J. Geophys. Res., 101, 14681-14696, 1996.

Hill, K. A., Shepson, P. B., Galbavy, E. S., and Anastasio, C.: Measurement of wet deposition of inorganic and organic nitrogen in a forest environment, J. Geophys. Res., 110, G02010, doi:10.1029/2005JG000030, 2005.

Hofzumahaus, A., Rohrer, F., Lu, K., Bohn, B., Brauers, T., Chang, C.-C., Fuchs, H., Holland, F., Kita, K., Kondo, Y., Li, X., Lou, S., Shao, M., Zeng, L., Wahner, A., and Zhang, Y.: Amplified trace gas removal in the troposphere, Science, 324, 1702-1704, 2009.

Horowitz, L. W., Fiore, A. M., Milly, G. P., Cohen, R. C., Perring, A., Wooldridge, P. J., Hess, P. G., Emmons, L. K., and Lamarque, J.-F.: Observational constraints on the chemistry of isoprene nitrates over the eastern United States, J. Geophys. Res., 112, D12S08, doi:10.1029/2006JD007747, 2007.

Hurst, J. M., Barket, D. J., Herrera-Gomez, O., Couch, T. L., Shepson, P. B., Faloona, I., Tan, D., Brune, W., Westberg, H., Lamb, B., Biesenthal, T., Young, V., Goldstein, A., Munger, J. W., Thornberry, T., and Carroll, M. A.: Investigation of the nighttime decay of isoprene, J. Geophys. Res., 106, 24335-24346, 2001.

Kerdouci, J., Picquet-Varrault, B., and Doussin, J. F.: Prediction of rate constants for gas-phase reactions of nitrate radical with organic compounds: A new structure-activity relationship, Chem. Phys. Chem., 11, 3909-3920, 2010.

Kim, D., Stevens, P. S., and Hites, R. A.: Rate constants for the gasphase reactions of $\mathrm{OH}$ and $\mathrm{O}_{3}$ with $\beta$-ocimene, $\beta$-myrcene, and $\alpha$ - and $\beta$-farnesene as a function of temperature, J. Phys. Chem. A, 115, 500-506, 2011.

Kim, S., Karl, T., Helmig, D., Daly, R., Rasmussen, R., and Guenther, A.: Measurement of atmospheric sesquiterpenes by proton transfer reaction-mass spectrometry (PTR-MS), Atmos. Meas. Tech., 2, 99-112, doi:10.5194/amt-2-99-2009, 2009.

Leungsakul, S., Jeffries, H. E., and Kamens, R. M.: A kinetic mechanism for prediting secondary aerosol formation from the reactions of $d$-limonene in the presence of oxides of nitrogen and natural sunlight, Atmos. Environ., 39, 7063-7082, 2005.

Lockwood, A. L., Filley, T. R., Rhodes, D., and Shepson, P. B.: Foliar uptake of atmospheric organic nitrates, Geophys. Res. Lett., 35, L15809, doi:10.1029/2008GL034714, 2008.
Lockwood, A. L., Shepson, P. B., Fiddler, M. N., and Alaghmand, M.: Isoprene nitrates: preparation, separation, identification, yields, and atmospheric chemistry, Atmos. Chem. Phys., 10, 6169-6178, doi:10.5194/acp-10-6169-2010, 2010.

Mahrt, L., Sun, J., Blumen, W., Delany, T., and Oncley, S.: Nocturnal boundary-layer regimes, Boundary-Layer Meteorol., 88, 255-278, 1998.

Makar, P. A., Fuentes, J. D., Wang, D., Staebler, R. M., and Wiebe, H. A.: Chemical processing of biogenic hydrocarbons within and above a temperate deciduous forest, J. Geophys. Res., 104, 35813603, 1999.

Mielke, L. H., Erickson, D. E., McLuckey, S. A., Müller, M., Wisthaler, A., Hansel, A., and Shepson, P. B.: Development of a proton-transfer reaction-linear ion trap mass spectrometer for quantitative determination of volatile organic compounds, Anal. Chem., 80, 8171-8177, 2008.

Mielke, L. H., Pratt, K. A., Shepson, P. B., McLuckey, S. A., Wisthaler, A., and Hansel, A.: Quantitative determination of biogenic volatile organic compounds in the atmosphere using proton-transfer reaction linear ion trap mass spectrometry, Anal. Chem., 82, 7952-7957, 2010.

Mihele, C. M. and Hastie, D. R.: Radical chemistry at a forested continental site: Results from the PROPHET 1997 campaign, J. Geophys. Res., 108, 4450, doi:10.1029/2002JD002888, 2003.

Mogensen, D., Smolander, S., Sogachev, A., Zhou, L., Sinha, V., Guenther, A., Williams, J., Nieminen, T., Kajos, M. K., Rinne, J., Kulmala, M., and Boy, M.: Modelling atmospheric OH-reactivity in a boreal forest ecosystem, Atmos. Chem. Phys., 11, 97099719, doi:10.5194/acp-11-9709-2011, 2011.

Muthuramu, K., Shepson, P. B., and O’Brien, J. M.: Preparation, analysis, and atmospheric production of multifunctional organic nitrates, Environ. Sci. Technol., 27, 1117-1124, 1993.

Nozière, B., Barnes, I., and Becker, K.-H.: Product study and mechanisms of the reactions of $\alpha$-pinene and of pinonaldehyde with OH radicals, J. Geophys. Res., 104, 23645-23656, 1999.

O’Brien, J. M., Shepson, P. B., Muthuramu, K., Hao, C., Niki, H., Hastie, D. R., Taylor, R., and Roussel, P. B.: Measurements of alkyl and multifunctional organic nitrates at a rural site in Ontario, J. Geophys. Res., 100, 22795-22804, 1995.

O’Brien, J. M., Czuba, E., Hastie, D., Francisco, J. S., and Shepson, P. B.: Determination of the hydroxy nitrate yields from the reaction of $\mathrm{C}_{2}-\mathrm{C}_{6}$ alkenes with $\mathrm{OH}$ in the presence of NO, J. Phys. Chem. A, 102, 8903-8908, 1998.

Orlando, J. J., Tyndall, G. S., and Wallington, T. J.: The atmospheric chemistry of alkoxy radicals, Chem. Rev., 103, 46574689, 2003.

Ortega, J., Helmig, D., Guenther, A., Harley, P., Pressley, S., and Vogel, C.: Flux estimates and $\mathrm{OH}$ reaction potential of reactive biogenic volatile organic compounds (BVOCs) from a mixed northern hardwood forest, Atmos. Environ., 41, 5479-5495, 2007.

Ortega, J., Helmig, D., Daly, R. W., Tanner, D. M., Guenther, A. B., and Herrick, J. D.: Approaches for quantifying reactive and low-volatility biogenic organic compound emissions by vegetation enclosure techniques - Part B: Applications, Chemosphere, 72, 365-380, 2008.

Patchen, A. K., Pennino, M. J., Kiep, A. C., and Elrod, M. J.: Direct kinetics study of the product-forming channels of the reaction of isoprene-derived hydroxyperoxy radicals with NO, Int. J. Chem. Kinet., 39, 353-361, 2007. 
Paulot, F., Crounse, J. D., Kjaergaard, H. G., Kroll, J. H., Seinfeld, J. H., and Wennberg, P. O.: Isoprene photooxidation: new insights into the production of acids and organic nitrates, Atmos. Chem. Phys., 9, 1479-1501, doi:10.5194/acp-9-1479-2009, 2009.

Paulot, F., Henze, D. K., and Wennberg, P. O.: Impact of the isoprene photochemical cascade on tropical ozone, Atmos. Chem. Phys., 12, 1307-1325, doi:10.5194/acp-12-1307-2012, 2012.

Peñuelas, J. and Staudt, M.: BVOCs and global change, Trends Plant Sci., 15, 133-144, 2010.

Perring, A. E., Bertram, T. H., Wooldridge, P. J., Fried, A., Heikes, B. G., Dibb, J., Crounse, J. D., Wennberg, P. O., Blake, N. J., Blake, D. R., Brune, W. H., Singh, H. B., and Cohen, R. C.: Airborne observations of total $\mathrm{RONO}_{2}$ : new constraints on the yield and lifetime of isoprene nitrates, Atmos. Chem. Phys., 9, 14511463, doi:10.5194/acp-9-1451-2009, 2009a.

Perring, A. E., Wisthaler, A., Graus, M., Wooldridge, P. J., Lockwood, A. L., Mielke, L. H., Shepson, P. B., Hansel, A., and Cohen, R. C.: A product study of the isoprene $+\mathrm{NO}_{3}$ reaction, Atmos. Chem. Phys., 9, 4945-4956, doi:10.5194/acp-9-4945-2009, 2009b.

Pfrang, C., King, M. D., Canosa-Mas, C. E., and Wayne, R. P.: Structure-activity relations (SARs) for gas-phase reactions of $\mathrm{NO}_{3}, \mathrm{OH}$ and $\mathrm{O}_{3}$ with alkenes: An update, Atmos. Environ., 40, 1180-1186, 2006.

Pinto, D. M., Tiiva, P., Miettinen, P., Joutsensaari, J., Kokkola, H., Nerg, A.-M., Laaksonen, A., and Holopainen, J. K.: The effects of increasing atmospheric ozone on biogenic monoterpene profiles and the formation of secondary aerosols, Atmos. Environ., 41, 4877-4887, 2007.

Pressley, S., Lamb, B., Westberg, H., Flaherty, J., Chen, J., and Vogel, C.: Long-term isoprene flux measurements above a northern hardwood forest, J. Geophys. Res., 110, D07301, doi:10.1029/2004JD005523, 2005.

Raupach, M. R.: A practical Lagrangian method for relating scalar concentrations to source distributions in vegetation canopies, Q. J. Roy. Meteor. Soc., 115, 609-632, 1989.

Ridley, B. A. and Grahek, F. E.: A small, low flow, high sensitivity reaction vessel for NO chemiluminescence detectors, J. Atmos. Ocean. Technol., 7, 307-311, 1990.

Rinne, J., Markkanen, T., Ruuskanen, T. M., Petäjä, T., Keronen, P., Tang, M. J., Crowley, J. N., Rannik, Ü., and Vesala, T.: Effect of chemical degradation on fluxes of reactive compounds - a study with a stochastic Lagrangian transport model, Atmos. Chem. Phys., 12, 4843-4854, doi:10.5194/acp-12-4843-2012, 2012.

Rollins, A. W., Kiendler-Scharr, A., Fry, J. L., Brauers, T., Brown, S. S., Dorn, H.-P., Dubé, W. P., Fuchs, H., Mensah, A., Mentel, T. F., Rohrer, F., Tillmann, R., Wegener, R., Wooldridge, P. J., and Cohen, R. C.: Isoprene oxidation by nitrate radical: alkyl nitrate and secondary organic aerosol yields, Atmos. Chem. Phys., 9, 6685-6703, doi:10.5194/acp-9-6685-2009, 2009.

Rollins, A. W., Smith, J. D., Wilson, K. R., and Cohen, R. C.: Real time in situ detection of organic nitrates in atmospheric aerosols, Environ. Sci. Technol., 44, 5540-5545, 2010.

Ruppert, L. and Becker, K. H.: A product study of the $\mathrm{OH}$ radicalinitiated oxidation of isoprene: formation of $\mathrm{C}_{5}$-unsaturated diols, Atmos. Environ., 34, 1529-1542, 2000.

Salmond, J. A. and McKendry, I. G.: A review of turbulence in the very stable nocturnal boundary layer and its implications for air quality, Prog. Phys. Geog., 29, 171-188, 2005.
Schmid, H. P., Su, H.-B., Vogel, C. S., and Curtis, P. S.: Ecosystematmosphere exchange of carbon dioxide over a mixed hardwood forest in northern lower Michigan, J. Geophys. Res., 108, 4417, doi:10.1029/2002JD003011, 2003.

Shepson, P. B.: Organic nitrates, in: Volatile organic compounds in the atmosphere, edited by: Koppmann, R., Blackwell Publishing Ltd., Ames, IA, 2007.

Sillman, S., Carroll, M. A., Thornberry, T., Lamb, B. K., Westberg, H., Brune, W. H., Faloona, I., Tan, D., Shepson, P. B., Sumner, A. L., Hastie, D. R., Mihele, C. M., Apel, E. C., Riemer, D. D., and Zika, R. G.: Loss of isoprene and sources of nighttime $\mathrm{OH}$ radicals at a rural site in the United States: Results from photochemical models, J. Geophys. Res., 107, 4043, doi:10.1029/2001JD000449, 2002.

Spanke, J., Rannik, Ü., Forkel, R., Nigge, W., and Hoffmann, T.: Emission fluxes and atmospheric degradation of monoterpenes above a boreal forest: field measurements and modelling, Tellus, 53B, 406-422, 2001.

Spittler, M., Barnes, I., Bejan, I., Brockmann, K. J., Benter, T., and Wirtz, K.: Reactions of $\mathrm{NO}_{3}$ radicals with limonene and $\alpha$ pinene: Product and SOA formation, Atmos. Environ., 40, S116S127, 2006.

Sprengnether, M., Demerjian, K. L., Donahue, N. M., and Anderson, J. G.: Product analysis of the $\mathrm{OH}$ oxidation of isoprene and 1,3-butadiene in the presence of NO, J. Geophys. Res., 107, 4268, doi:10.1029/2001JD000716, 2002.

Stroud, C., Makar, P., Karl, T., Guenther, A., Geron, C., Turnipseed, A., Nemitz, E., Baker, B., Potosnak, M., and Fuentes, J. D.: Role of canopy-scale photochemistry in modifying biogenicatmosphere exchange of reactive terpene species: Results from the CELTIC field study, J. Geophys. Res., 110, D17303, doi:10.1029/2005JD005775, 2005.

Tan, D., Faloona, I., Simpas, J. B., Brune, W., Shepson, P. B., Couch, T. L., Sumner, A. L., Carroll, M. A., Thornberry, T., Apel, E., Riemer, D., and Stockwell, W.: $\mathrm{HO}_{\mathrm{x}}$ budgets in a deciduous forest: Results from the PROPHET summer 1998 campaign, J. Geophys. Res., 106, 24407-24427, 2001.

Trainer, M., Buhr, M. P., Curran, C. M., Fehsenfeld, F. C., Hsie, E. Y., Liu, S. C., Norton, R. B., Parrish, D. D., Williams, E. J., Gandrud, B. W., Ridley, B. A., Shetter, J. D., Allwine, E. J., and Westberg, H. H.: Observations and modeling of the reactive nitrogen photochemistry at a rural site, J. Geophys. Res., 96, 3045-3063, 1991.

Tuazon, E. C. and Atkinson, R.: A product study of the gas-phase reaction of isoprene with the $\mathrm{OH}$ radical in the presence of $\mathrm{NO}_{\mathrm{x}}$, Int. J. Chem. Kinet., 22, 1221-1236, 1990.

USEPA: Estimation Programs Interface Suite ${ }^{\mathrm{TM}}$ for Microsoft Windows, v 4.0, United State Environmental Protection Agency, Washington, DC, USA, 2010.

Werner, G., Kastler, J., Looser, R., and Ballschmiter, K.: Organic nitrates of isoprene as atmospheric trace compounds, Angew. Chem., 38, 1634-1637, 1999.

Wolfe, G. M. and Thornton, J. A.: The Chemistry of AtmosphereForest Exchange (CAFE) Model - Part 1: Model description and characterization, Atmos. Chem. Phys., 11, 77-101, doi:10.5194/acp-11-77-2011, 2011.

Wolfe, G. M., Thornton, J. A., Bouvier-Brown, N. C., Goldstein, A. H., Park, J.-H., McKay, M., Matross, D. M., Mao, J., Brune, W. H., LaFranchi, B. W., Browne, E. C., Min, K.-E., Wooldridge, 
P. J., Cohen, R. C., Crounse, J. D., Faloona, I. C., Gilman, J. B., Kuster, W. C., de Gouw, J. A., Huisman, A., and Keutsch, F. N.: The Chemistry of Atmosphere-Forest Exchange (CAFE) Model - Part 2: Application to BEARPEX-2007 observations, Atmos. Chem. Phys., 11, 1269-1294, doi:10.5194/acp-11-12692011, 2011a.

Wolfe, G. M., Thornton, J. A., McKay, M., and Goldstein, A. H.: Forest-atmosphere exchange of ozone: sensitivity to very reactive biogenic VOC emissions and implications for incanopy photochemistry, Atmos. Chem. Phys., 11, 7875-7891, doi:10.5194/acp-11-7875-2011, 2011 b.
Wu, S., Mickley, L. J., Jacob, D. J., Logan, J. A., Yantosca, R. M., and Rind, D.: Why are there large differences between models in global budgets of tropospheric ozone?, J. Geophys. Res., 112, D05302, doi:10.1029/2006JD007801, 2007.

Zhang, L., Brook, J. R., and Vet, R.: A revised parameterization for gaseous dry deposition in air-quality models, Atmos. Chem. Phys., 3, 2067-2082, doi:10.5194/acp-3-2067-2003, 2003. 